\title{
ANALYTICAL METHODOLOGY FOR REGENERATING URBAN IDENTITY AS A SUSTAINABLE CULTURAL HERITAGE LANDMARK IN EGYPT, CASE STUDY: EGYPTIAN MUSEUM(GEM)
}

\author{
Nisreen Samy Abdeen \\ Assistant Professor in Architectural Department, Heliopolis University (HU)
}

\begin{abstract}
:
The paper aims to create analytic methodology for the nation landmark urban context for long term expansion, to cope with the increasing of visitors, with conserving the new location of GEM museum, for being near to the Pyramids plateau. The GEM urban context is considered to be an effective sustainable landmark in regulating the urban extension in Giza, and conserving the archaeological site of the western desert "Memphis and its necropolis with the Pyramids Field" as a World Heritage. However, the existed land use of the urban context is not matching with the nation landmark, as there is a great obstacle in its accessibility and approach, besides being near to slums. So, the paper suggests analytic methodology for urban development to be an effective entertainment, by encouraging walkability to reflect positive social, and environmental impact on the GEM image. Regarding display control and new directions for the new planned usages surrounding it, so as to construct urban identity guideline. Giza Plateau is one of the most important world heritages by the UNESCO, where it should be planned in a controlled way, coping with its value. The main goal is to create unique identity of our city that plays a great role in providing reference points for future developments. (Evans, G. 2005, p. 42).
\end{abstract}

\section{Keywords}

nation landmark, urban Development, urban identity, historical surroundings, urban governance.

\section{1-Introduction}

Historic urban centres play a great role in identifying city urban identity (Boussaa, D.2003; pp. 51-60). Furthermore, Scheffler et al. shows the importance of Urban regeneration in gentrification of historic centres ' with its emotive urban issues, to have better updated land use. (Scheffler, N.2009; pp. 9-13). In addition, protecting and reviving the mainstream out of rapid urbanization to protect the tangible and intangible qualities that have disappeared. The paper emphasis on the landmark heritage importance in Egypt, referring to UN Habitat [Carrion, F.M. 2005) as a city urban identity. As it is affects the environment by being a socio-economic value, that afterwards, "As a result, urban planning is important to preserve cultural heritage, in shaping the city's identity". (Rashed, M. G. 2015, 165-172). The role of cultural heritage is fulfilling citizens needs for identity. In the same line, Evans, Tweed \& Southerland focused on the regeneration interventions in historic urban areas matching with the life change, to avoid "the sacking of a city" that is known by Jacobs [Evans, G. 2005, 42]. Where the role of many governments is to plan 
monumental urban areas "if change is inevitable, then it should be controlled to regenerate continuity with the past". The role of urban planning in the past did not withstand the test of time in the discontinuity of contemporary urban structures.

\section{2- The role of Sustainable Urban Development:}

The Sustainable Urban Development is a basic role in solving our fact existed problems, especially our nation landmarks, as it upgrades its site facilities and services in a holistic way, that will reflect by a positive influence on its surrounding environment. Urban development will manage this monumental region, to have an effective way in its environment quality, in assessing its performance for a long, and short period of time.so it plays a great role in overcoming the co-void virus by improving mental health, by providing walkability in a big span through different nodes, to promote movement, with its future needs. Complexity of usages is needed as an aspect to cope with change and fun, to understand the habit user life style, to improve connectedness in a safe way. Sustainable urban streets are a holistic solution for community equity, ecology, economy and environment, as it creates liveable communities, in compacted cities, by relaying upon its natural resources, to reduce energy consumption, as a healthy community. (Heterotopolis, La Verne Wells-Bowie, 2000; pp. 451455). Hence the urban development encompasses the spatial, social, and demographic processes. From this methodology, the paper can assess the functional dimension determine How are urban spaces used, matching with the social dimension, how it can be

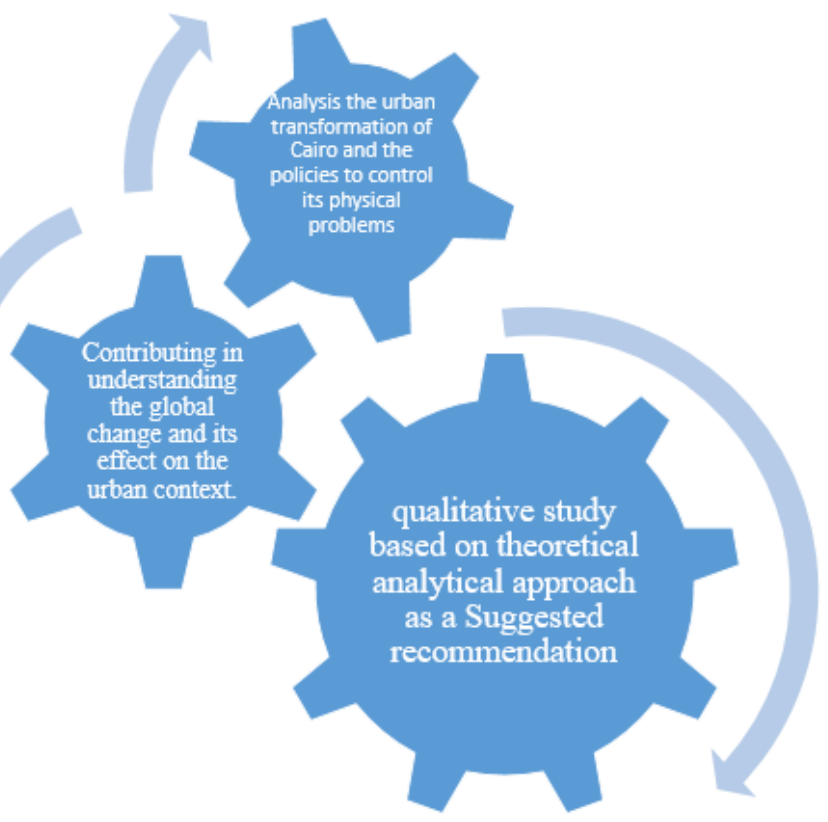

Fig (1): shows the analytic methodology for regenerating urban identity, source: the researcher used in an efficient way? defining he multiple facets of "urban life". Create the urban identity as urban planning by applying conceptual framework city through designing urban transformation changes, as it is complex. The distinction between urban development and urban planning, as a first intricacy. It indicates the terminology scope in urban space. (Carrion, F.M. 2005) 

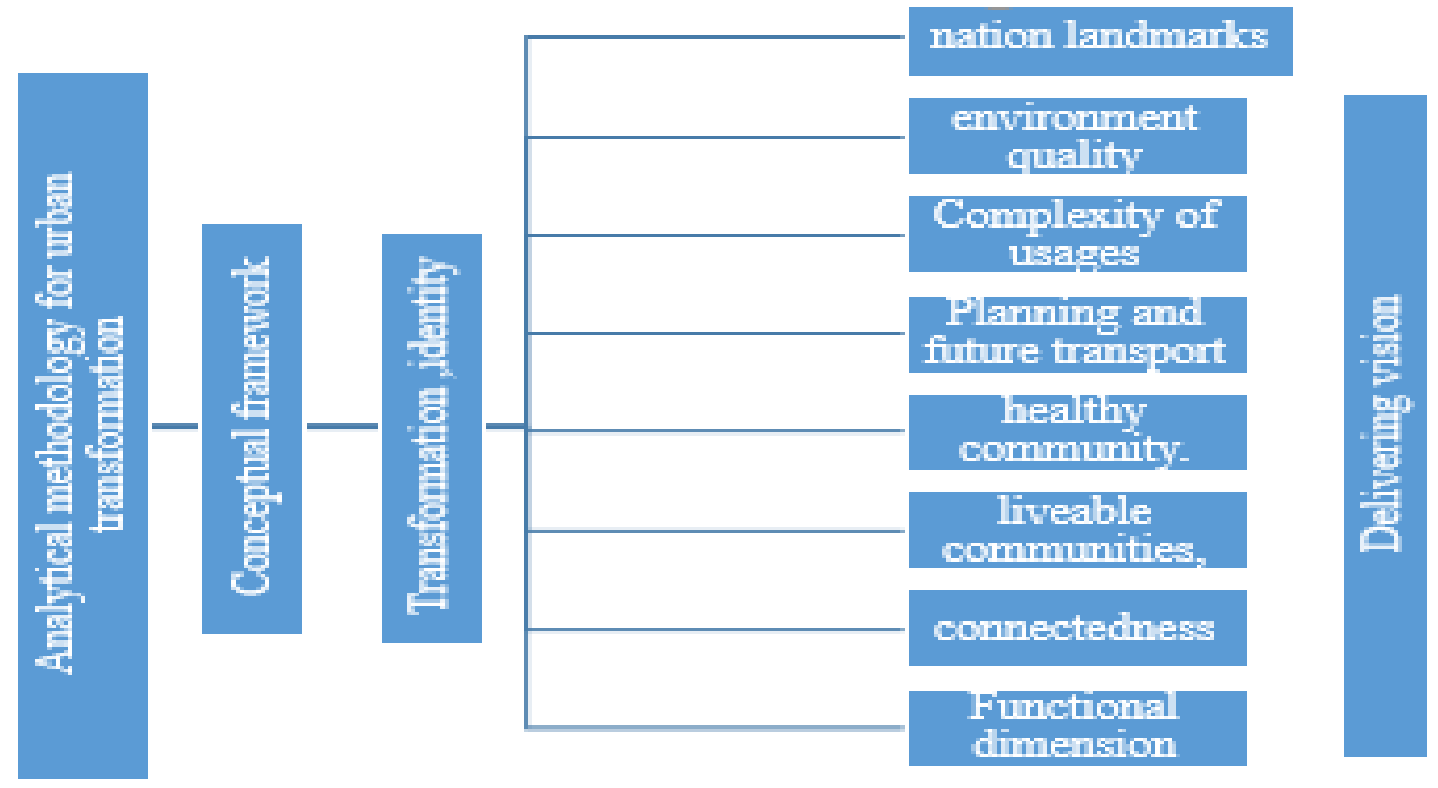

Fig (2) shows the analytic methodology for the urban transformation, source: the researcher

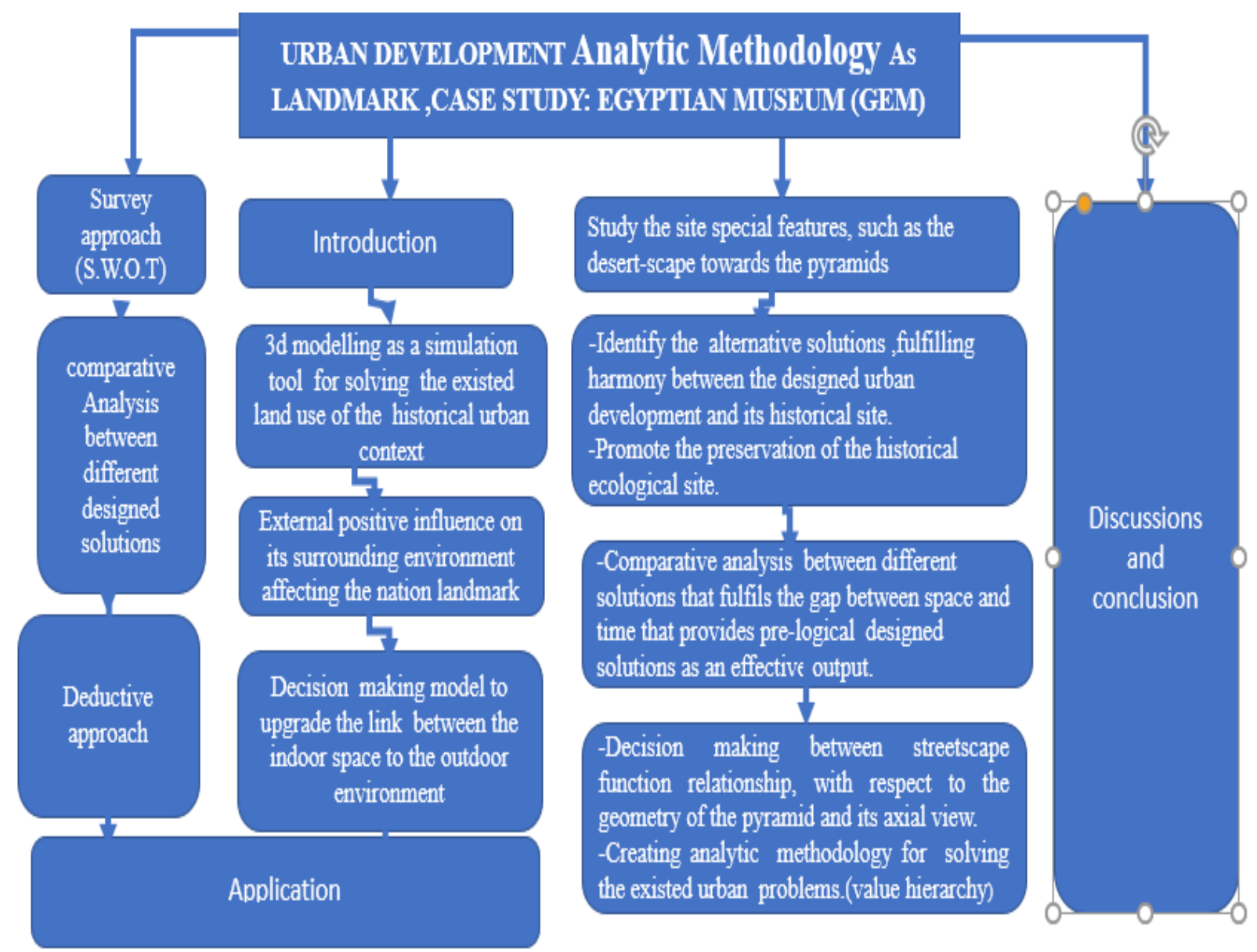

Fig (3): shows analytic methodology as urban development for nation landmark, case study GEM museum, source: the researcher 


\section{3-The urban identity dimensions:}

Urban identity is the city image phenomenon that connects people to "their" city as it is reflects on different factors: as "sense of unity" is shown in its buildings, the streets or its structural way. Where functional level plays a great role in urban Identity through unique architectural landmarks. The problem nowadays, Egypt is facing is the loss of historical buildings as a result of urban planning restructuration. So the paper highlighted on reviving this important symbol for the connection of people to their city. (Conserv. Manag. Archaeol 2014, 16, 5-16)

Table (1) shows the analytic methodology for creating city landmark, (Gharib, R. 2014, 16, 5-16)

\begin{tabular}{|c|c|}
\hline $\begin{array}{l}\text { Analytical methodology for creating city } \\
\text { landmark }\end{array}$ & Urban development planning \\
\hline Identity & $\begin{array}{l}\text { Studying the historical monument } \\
\text { surrounding, assessing its impact as it } \\
\text { affects the city silhouette. } \\
\text { Distinguish, and assess } \\
\text { the most effective indicator affecting urban } \\
\text { identity and the urban context as it is a } \\
\text { central landmark. } \\
\text { Define urban identity through emphasising } \\
\text { on how can a historical city layout be } \\
\text { sufficiently taken into account? } \\
\text { urban identity is identified by the urban } \\
\text { landscape, architectural style with its } \\
\text { remarkable buildings and monuments, to } \\
\text { create a unique "character" of a city }\end{array}$ \\
\hline Feasibility & $\begin{array}{l}\text { study the feasibility of the creative designs } \\
\text { as a necessary financial means. }\end{array}$ \\
\hline Flexibility & $\begin{array}{l}\text { Flexibility is in having multi-functional } \\
\text { buildings as an independent development. } \\
\text { As providing the shift to alternative } \\
\text { locations in urban development. }\end{array}$ \\
\hline Functionality & $\begin{array}{l}\text { Verifying the choice of the right location of } \\
\text { the needed land use, assessing if it has a } \\
\text { specific character. Emphasising on the } \\
\text { compatibility of land uses with each other of } \\
\text { urban spaces. }\end{array}$ \\
\hline Diversity & $\begin{array}{l}\text { It highlights on the spatial diversity in the } \\
\text { city as a holistic entity, to have a mix of } \\
\text { different usages. It measures the extent of its } \\
\text { social, and cultural, impact on the urban } \\
\text { identity. }\end{array}$ \\
\hline
\end{tabular}




\begin{tabular}{|l|l|}
\hline Aesthetics & $\begin{array}{l}\text { Asses the creativity of the function if it is } \\
\text { coping with the urban context, or only up- } \\
\text { to-date, as it has to be creatively } \\
\text { subjective criterion as a pleasant } \\
\text { atmosphere. }\end{array}$ \\
\hline Resource efficiency & $\begin{array}{l}\text { Sustainability plays a great role as a strong } \\
\text { factor in urban development for having } \\
\text { subsequent usage, as conservation resource. } \\
\text { Mainly it assess its ecological impact as a } \\
\text { method in maintaining its aesthetic value. }\end{array}$ \\
\hline Process capability & $\begin{array}{l}\text { Studying the Urban planning measures with } \\
\text { different forms. }\end{array}$ \\
\hline Profitability & $\begin{array}{l}\text { Studying the cost management of usage for } \\
\text { urban planning projects as a running costs } \\
\text { for maintenance, especially the streetscape. }\end{array}$ \\
\hline
\end{tabular}

\section{3-Approach of urban transformation in creating the city urban identity:}

In this article the paper shows the importance of the city image in having balance between social, cultural and ecological aspects. The achievement in solving urban issues can be applied by implementing methodological guidelines of 'good urban governance' as a main demand to control the development of urban space, as Richard Sennett described it, "user friendly" .To achieve these urban development goals by creating public space and urban policy to reduce dispersed investments (e.g. compact city, smart growth), in controlling urban sprawl, by implementing coherent urban development, system of land acquisition to protect cultural landscape. Added to it sustainable development aspects, in renewing movement, known as New Urbanism which was established in the 1990s in the United States, referring to, American urbanists Andrés Duany and Elizabeth Plater-Zyberk who created urban solutions as a guideline, for cities urban, based upon the city traditional model, and assessing it upon its value of public and private urban spaces. They referred to neo-traditional models of the city created by Jane Jacobs, Leon Krier and Christopher Alexander. It can be achieved by promoting complex core urban areas and improving their attractiveness for pedestrian traffic, such as underground passages, footbridges or traffic lights. So the research focus on the clear relations between public and private space defined by greenery, vestibules, and fences to fulfil the aim of mixed communities. (Bentley, I. 2005; Available online: http://www.icvbc.cnr.it/all\%202.pdf (accessed on 15 2017). There is a great contribution in distinguishing the urban identity of cities, referring to the New Urbanism as a traditional urban planning movement that was criticised for implementing static rules of urban. On the other hand, Contemporary architects- Rem Koolhaas, who presented in his urban manifesto 'The generic city' a thesis that the rules of traditional urbanism should be rejected as the city's identity, as it is an obstacle to think freely about its future. He based his thesis on the inevitability of changes out of life change, suggesting ex definition of uncertainty, and discontinuity. Therefore, the paper highlights on observing the real fact and study its reflection on the surrounding.

Good urban governance approach should implement the new conceptualisations in urban transformation. As modernism had changed the political aspects of urban planning, ignoring its social character. "The interest in urban governance among academics, 
practitioners and politicians widened in the 1990s. After the United Nations conference in Nairobi in 2002 was held, 'good urban governance' principles have become a global standard in urban policies. This concept is advocated as a strategy for upgrading the quality of life in urban settlements in developing countries where the sustainable urban policies avoid rapid urbanisation. 'Good urban governance' is assessed by reassessing these standards "in connection to a solid frame of reference". (. Adham, K. 2008; pp. 218257.

\section{4-The role of space and time in generating city layout:}

To testify the urban context Phenomenology through time, by examining the comfort in the outdoor, in providing walkability, with seeing the aesthetical monumental view, saving it in minds by its landmarks. Sennett observes, the 'smart city' approach where technology is used to generate city layout so as to achieve the best relation between space and time. He argues that smart technology should be used to co-ordinate rather than to prescribe and pre-organise. The paper highlights on suggesting analytic methodology as a guideline to upgrade and develop Gem urban context as it is a landmark for its historical surrounding, and apply sustainability as a holistic identity to overcome the urban gap on the regional level, such as public services quality. These objectives of sustainable urban development are classified into social, environmental, and economic categories, that reflects on its urban fabric character. So the research focused on studying the existing character of GEM urban context by applying S.W.O.T analysis, by studying the existing fact, applying site analysis, shown in its mental maps, such as building heights, conditions, construction, and land use maps to strengthen the weakness, by suggesting different alternative solutions that cope with its monumental pyramid plateau. The reason for building Gem museum in the underground level, and creating roof garden surrounding is it to provide shade inside the inverted stepped building, and second concept creating oasis in the desert by letting the museum surrounded by water. So the urban development should respect the pyramid Monumental value. However, the external circulation in the outdoor should be as a reflection of urban landmark to identify its vision from different axial views. The research highlights on the shortage resulted of the rapid urban agglomeration of structure, cause a rapid deterioration of the archaeological sites out of bad land use. The slums are a dangerous threaten for this monumental region, because of breaking the national regulations that cause the increase in the informal housing settlements in the area. In addition to this the price of land increases along these road networks, due to the road systems development, that links between the new desert satellites and Cairo city, that attracts middle income settlements to grow alongside this region. So the research strengthens these threatens and shortage as an opportunity goal, as follows.

\section{5- Effective Sustainability in Applying Integration with Urban Context:}

as mapping means to apply the complex system in its land use in an effective sustainable way, with its environmental, social, economic It emphasizes the need for integration and examining system components together rather than in isolation, which definitely fits within the notion of sustainability. This research aims to establish analytic methodology which envisages the current processes for creating a nation landmark near ancient pyramids and typical rural Egyptian village and develop a set of indicators, which allow 
the interactions between factors to be tracked and the impact of policy interventions to be assessed.

5-1- Apply the S.W.O.T. analysis for the existed urban context surrounding, with its sustainability constraints, upon the current conditions in site.

5-2- design different urban development design solutions for the existed historical site, as a required action, to upgrade its urban context, that depends on its particular region conditions. (Bowers 1997, p184).

5-3-achieving the most appropriate sustainable solution for urban development, based upon Conserving the valuable Environment, and natural resources.

5-4- creating new land use as economic development for the existed urban, to create appropriate market demand, coping with its historical environment.

5-5- Choosing the ideal solution, for social urban development, to apply the equity

\section{6-Studying The Urban Region Ecological Impact:}

The preservation of the Giza Pyramids visual corridor and the plateau view through planning sustainable strategies including formal buildings, land-use constraints, and planting of desert shading trees, landscape. Improvement of the environmental quality of the monuments surrounded areas focusing on archaeological areas. Stimulating alternative urban solutions to feel its real impact as investment opportunities. The efficient ways of avoiding solar irradiation in hot climates. The museum structure is placed in the underground level, that emerge from the desert and form a concentric panoramic points, since underground floors maintain constant temperatures in all seasons. The Limitation of the initiative of new planned settlements such as the development of Al-Zohour and Hada'ek el Ahram settlement. Conservation of Egyptian raw materials, including their specific problems, Urban Development Urban Sprawl, Standardization, technical examination Conservation Treatment, and Data management.

\section{7-Upgrade the Urban Economic Development as a nation Local economy}

By studying region Social needs, to maximize the use of vacant land, in absorbing the population growth needs, as a region needs, and housing Supply. Urban development can be achieved by creating recreational activities by additional opportunities. However, upgrading safety can be achieved, by increasing facilities and amenities, decreasing Crime rate. So Ameliorating economic revenue is applied by converting the region into a sustainable urban identity, highlighting on the ancient pyramid, reducing the rate of patients suffering from endemic diseases, by increasing landscape. Facilitating accessibility to reach the region landmarks. Providing emergency services and security is essential in each node to conserve Agricultural Land as an Environmental Quality Protection.

7-1-studying the region Economic dimension: Studying the travel time to different nodes, amenities, and if it is walkable or not, and find the solutions to provide walkability.

-City product per person as an Environmental dimension:

-Studying the available transportation and the Use of private car. 
7-2-Urban development assessment as sustainability ranking: In this method sustainable urban indicators are classified upon their importance values i.e. environmental, economic, social that are essential in any sustainability assessment. The area destined to be the new Egyptian museum is 117 Fadden's (50 Hectares = 480000sq.m.) and belongs to the Supreme Council of Antiquities (SCA).

\section{8- Sustainability perceptions in upgrading urban identity:}

Systems for sustainable approach for developing region, as landmark model is to promote systematic interrelationships, by upgrading its network in a sustainable way, by planting it, using raw materials to integrate it with its urban context.

8-1- Applying Simulation Systems to all urban solutions: Identifying the most appropriate leverage points that will reflect positivity on the urban context. (Bellinger 2004). upgrade "Systems Thinking" recognized the need for a better way of testing new ideas about social systems in the same way as the ideas in engineering can be tested. by computing simulation techniques. (Aronson 1998).

8-2-Planning nation streets in an Environmental way: By decreasing the noise pollution, avoiding the crowded streets, to decrease the energy consumption, from different utilities, and amenities, such as traffic, as it exacerbated the greenhouse effect providing different kind of transportation. Whereas adjusting connectivity between street network, needs using natural resources, and respecting built environment.

\section{9-Define the region quality of space:}

9-1-Studying the museum approach from the main streets, and main nodes to the dark narrow tunnel, that transforms the visitor's feeling from mystery darkness to light to create a virtual Hypostyle hall, reflecting by the monumental spirit.

9-2-Defining the museum region image at day and at night, by directing the lights shooting to the sky, coping with the monumental landmark, creating specific urban identity, and different experience for its central open plaza, as walkable approach.

\section{9-3-Creating a contrast in the space spirit by dark and light, letting light penetrates from all streetscapes, directed to the monumental pyramid, in a diffuse manner that the visitor will not be able to determine where the light comes as a wise journey of exploration into ancient Egyptian history.}

\section{9-4-Creating street network} harmony: Creating the node as a rule for gathering for cultural experiences for all visitors as an efficient dissemination of information for different view

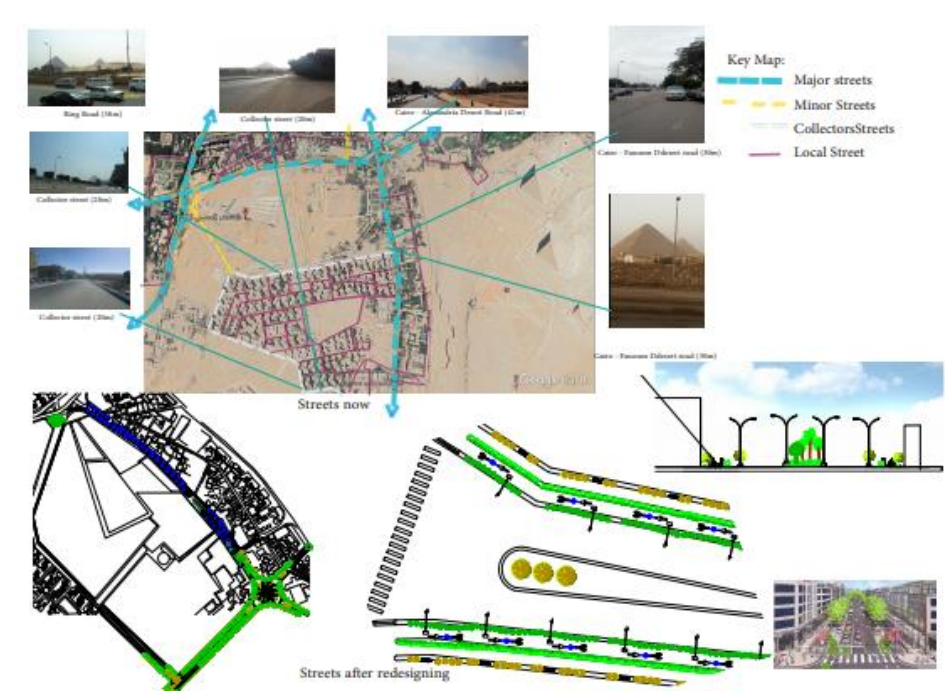

Fig 4 shows GEM museum urban context as a redesign suggestion, focusing on the four nodes as a varied 
aspects from different cultures, as support guide to the museum, as a source of enjoyable. Applying the green plaza as an exhibit for ancient Egyptian periods. Where The site harmony starts by the intersection between antiquity and modernity. street network is a basic fundamental unit to provide healthy flexibility movement as a comprehensive transit meeting points, as evolution of transportation system, coping with its valuable place, using natural resources that are durable. Where planning the urban solution upon using recycling materials in constructing streetscape to decrease consumption of material resources. The material selected for the museum are between modernity of bulky concrete massive buildings and the ancient stone.

9-5-Upgrading Region Liveliness: Provide recreational culture entrainment, compatible with the monumental region.by planting trees aligned with aspects by placing social interaction with economic development. liveliness is achieved in streetscape by assessing sustainable streetscape in these indicators, streetscape comfort, environment quality, maintain effective communication, compatible liveliness, streetscape comfort, safety with touristic region, and traditional fabric in streets as a method in Upgrading cultural heritage.

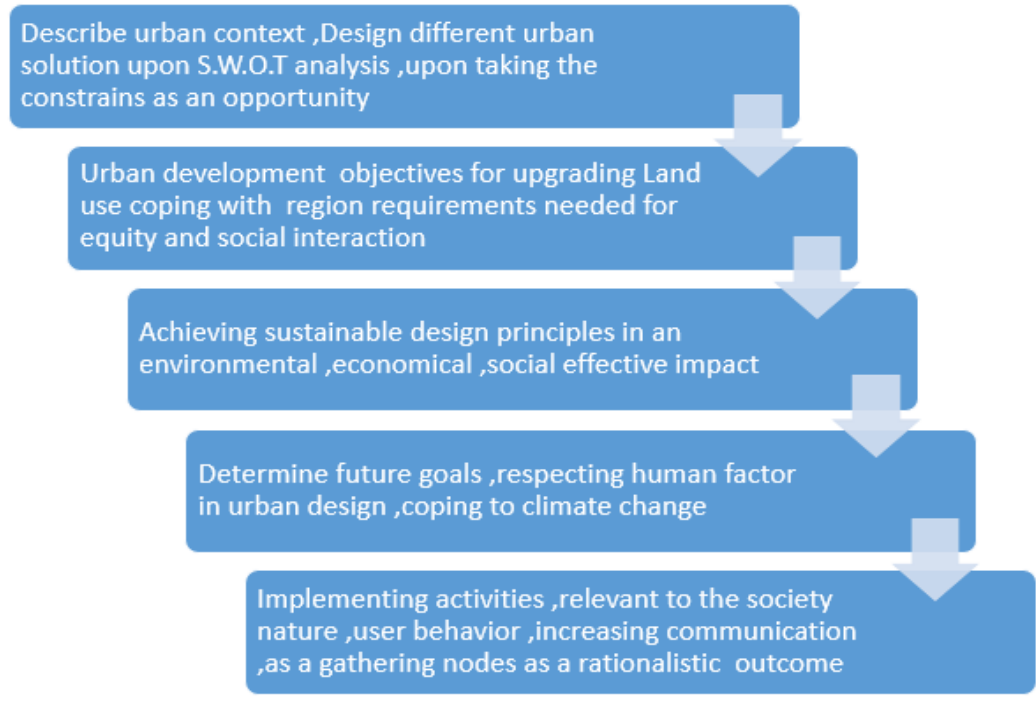

Fig 5: shows GEM museum urban development phases as a redesign suggestion, focusing on the four nodes as a varied pedestrian routes surrounding it, to facilitate its accessibilitv. and to preserve the identitv of this region. bv the researcher

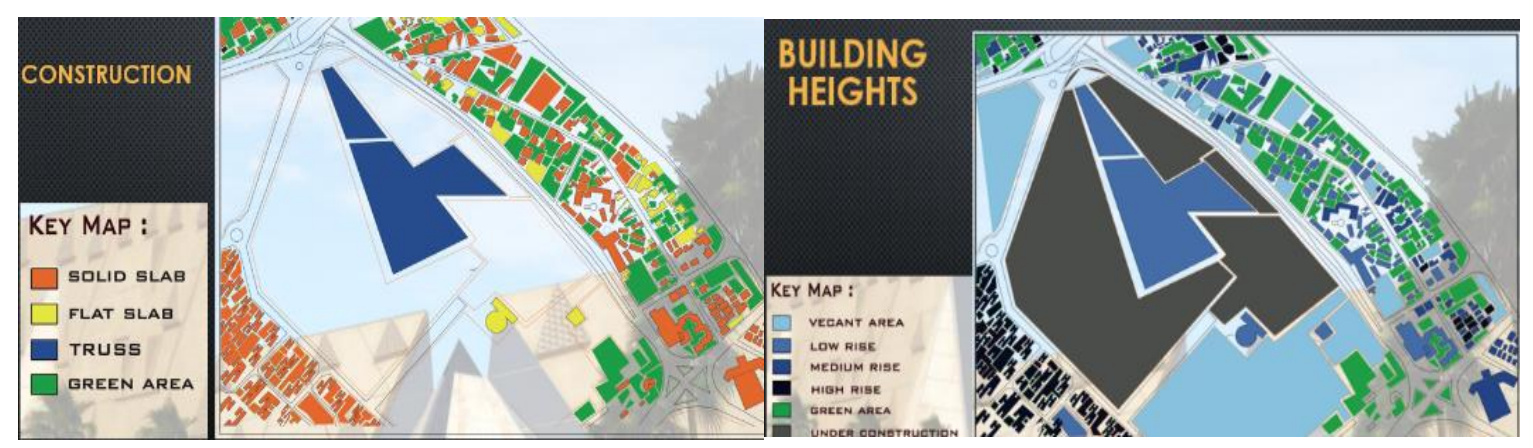

Fig 6: shows analytic survey for existed fact of GEM museum region urban context for nation landmark, construction and building heights mental maps, by the researcher. 


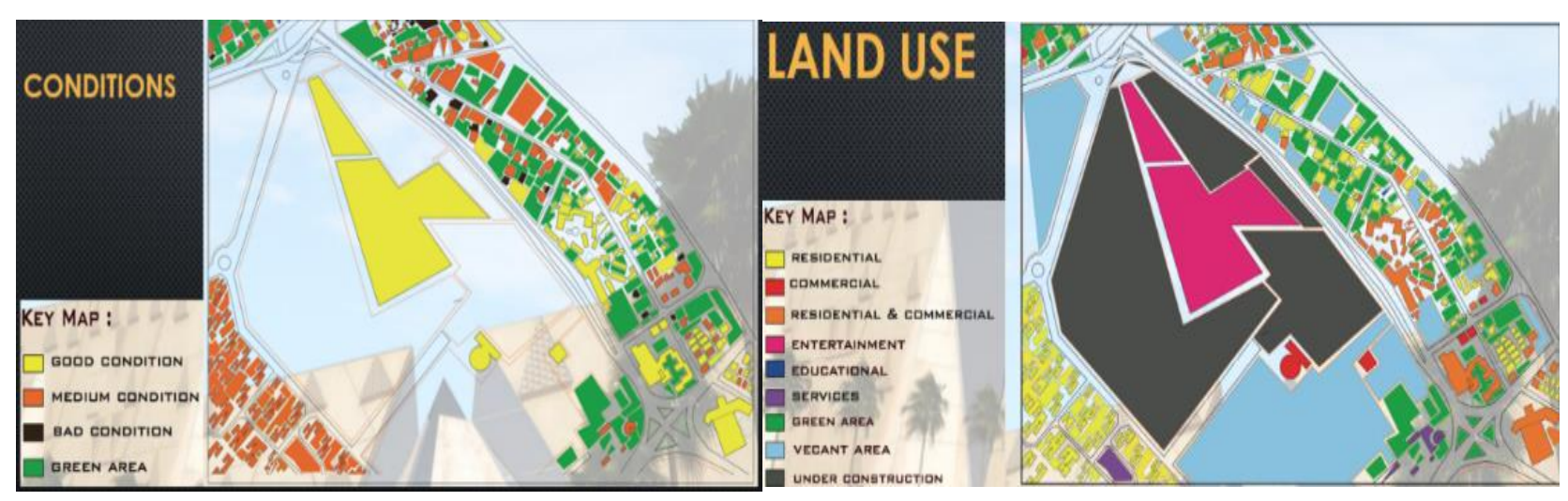

Fig 7: shows GEM museum land use, conditions mental map phases, by the researcher

9-6- Identifying the outdoor passages by courtyards as an effective urban development: Creating Courtyards, gardens, is a main urban development goal, to identify the passages in the open outdoor streets, and paths. So connecting the outside environment visually to the pyramids, by controlling the building heights, by burying the GME museum in the underground level of the desert-scape in the upper pyramid plateau. In addition, primary access to special non-chronological and exhibits galleries below the grand ramp. Create different Plazas in different gathering points, and on the museum roof. The idea in how to dissolve the large structure of the museum as a mirage phenomenon as an urban solution in submission to the strong presence of the pyramids. Creating complex facilities, with terraced parks, the planted roof garden for the existed buildings acts as an environmental solution, create roof garden in terms of cooling, achieving good atmosphere in the outdoor, reflected in the door Environment. Where the GEM museum approach is planned by planting a huge park in the centre, as a Piazza. Increasing The Piazza in the region, in the central, partial nodes to purify the air in the outdoor environment, especially in the gathering spaces, to let liveable day, and night by recreational activities, and let the nodes active even when the museum is closed. ( Law, R.;. 2012, 1, 131-147.

9-7-Egyptology as interactive cultural source in central nodes: Contribute the cultural environment, through complex activities, that is located in the centre of Egyptology, to express the world of ancient Egypt at different modes as an interactive cultural resource. 


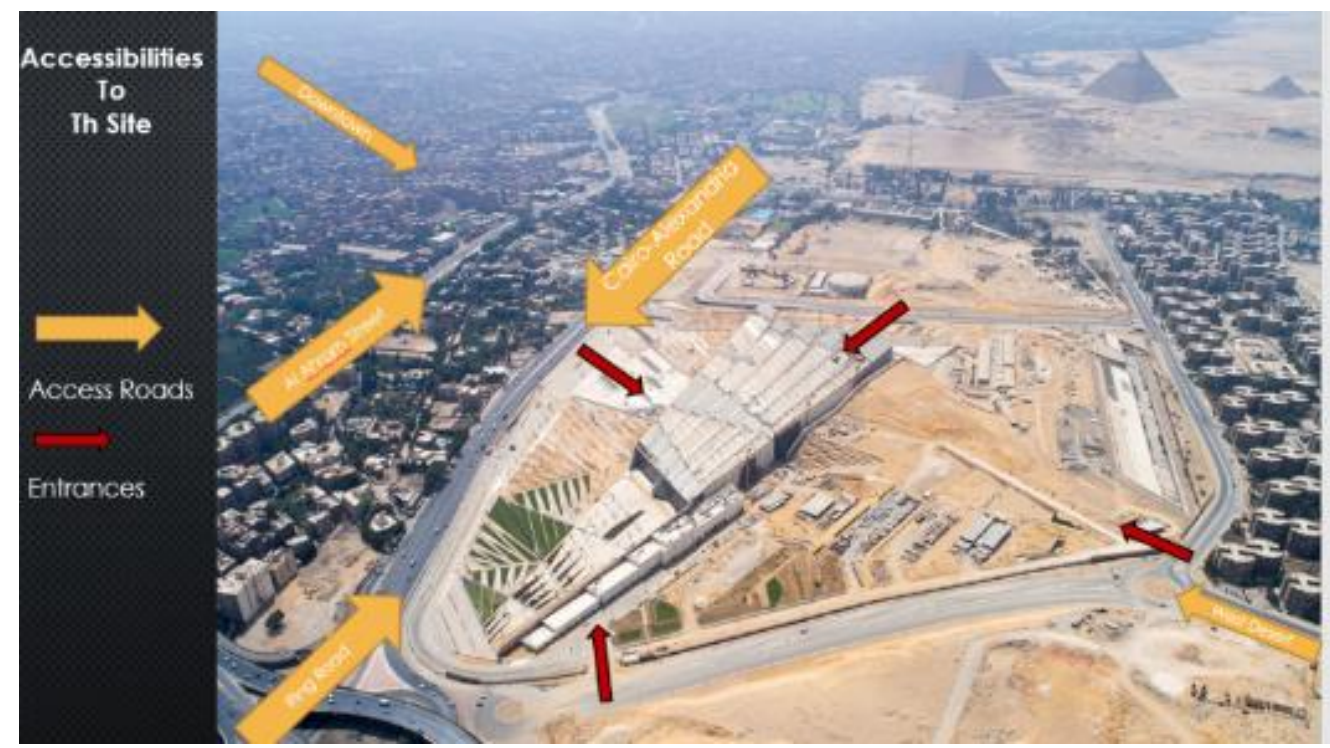

Fig 8: shows GEM museum accessibly, showing main entrance approach.

\section{Redesign Node 2}

Design Concept: was inspired from the Pyramids of Giza through

out applying the shapes of geometric figures as Triangles
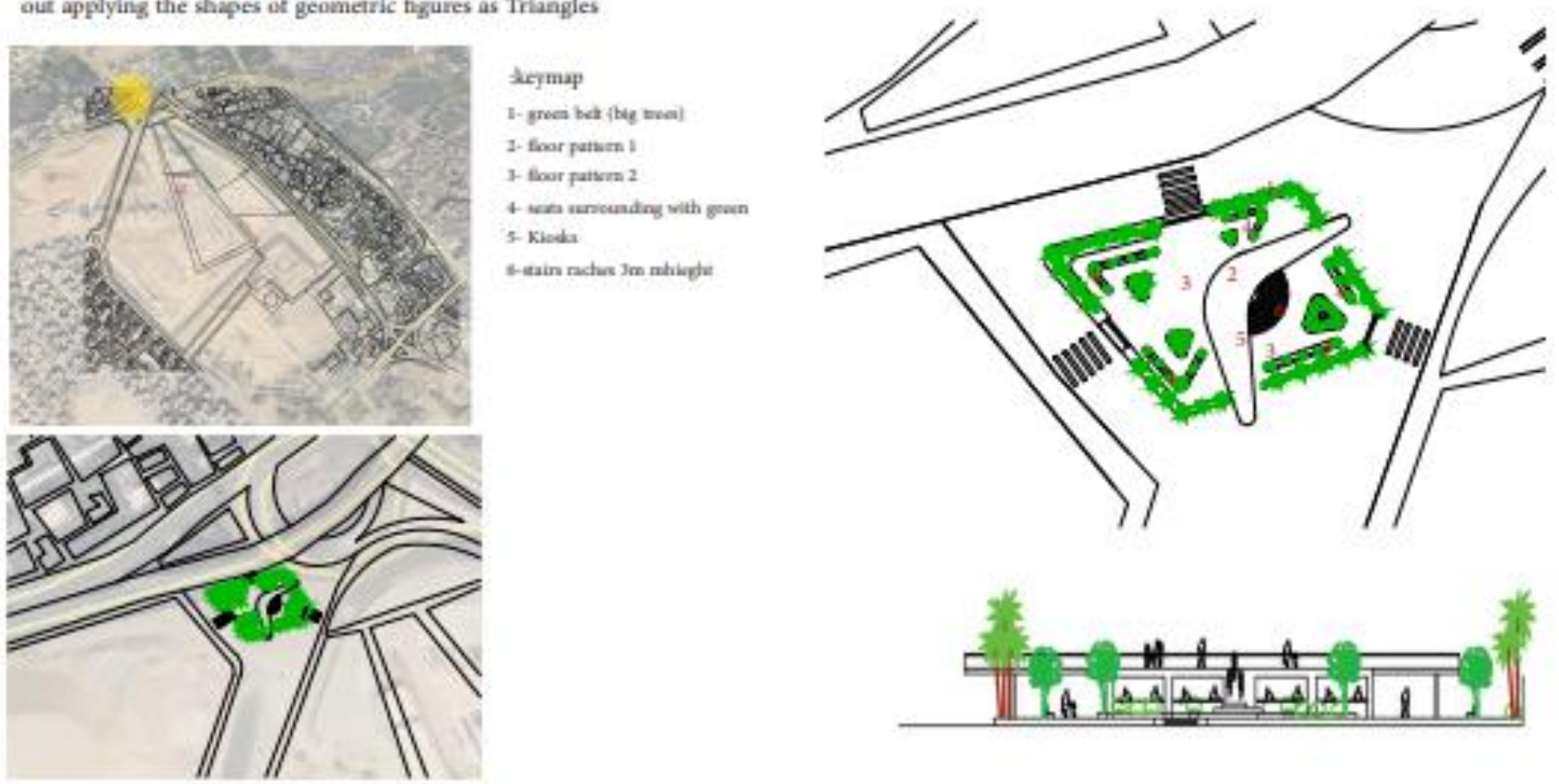

Fig 9: shows GEM museum urban context as a redesign suggestion, focusing on the four nodes as a varied pedestrian routes surrounding it, to facilitate its accessibility, and to preserve the identity of this region 


\section{0-Primary goal of urban development:}

The paper focused upon creating basic guidelines for urban development to achieve the city aims., as a Sustainable urban solution with different objectives, based upon existing

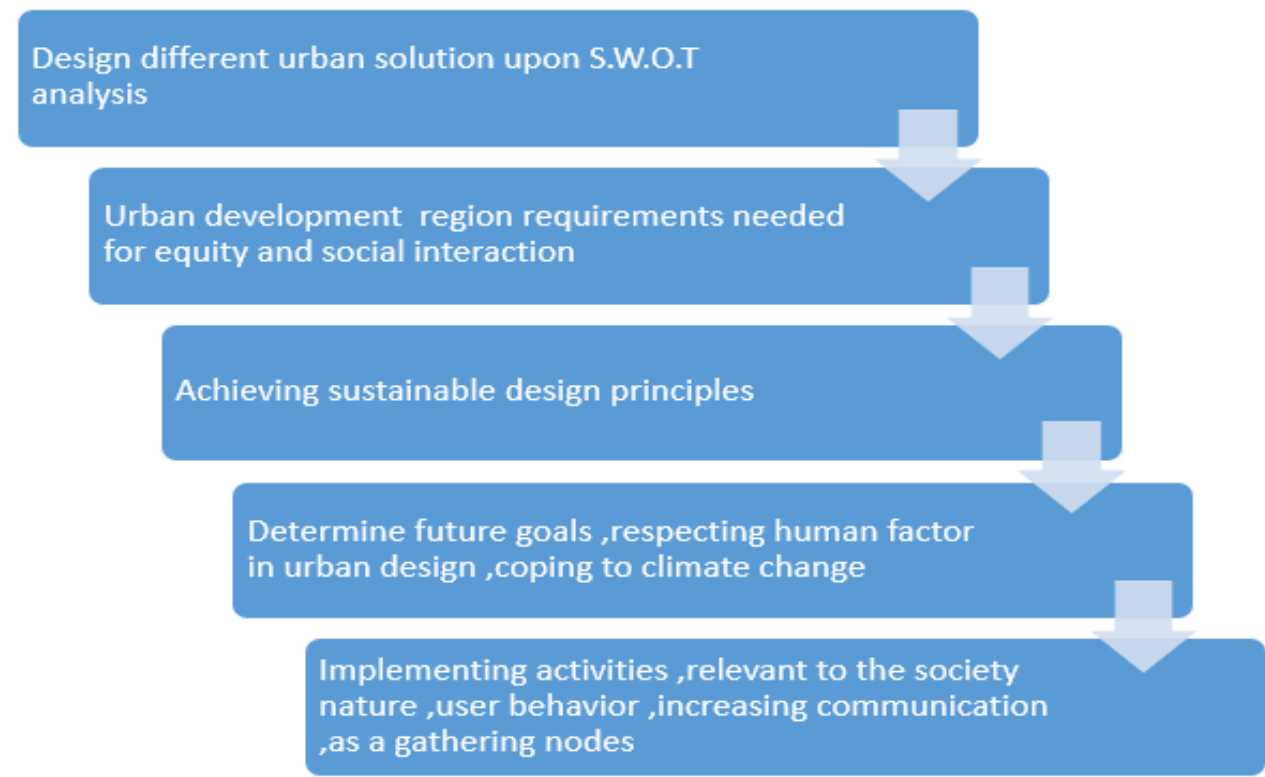

Fig 10: Shows GEM museum urban development as qualitative method, the researcher

site conditions. Analysing the site circumstances by strengthen the weakness as opportunities for urban design. Francois (2010), "urban development plays a great role in methods of urban (Development and Planning Project of the Local Urbanism Plan, Territorial Coherence Plan...)". Improving the sustainable urban quality in developing the city outdoor environment as an
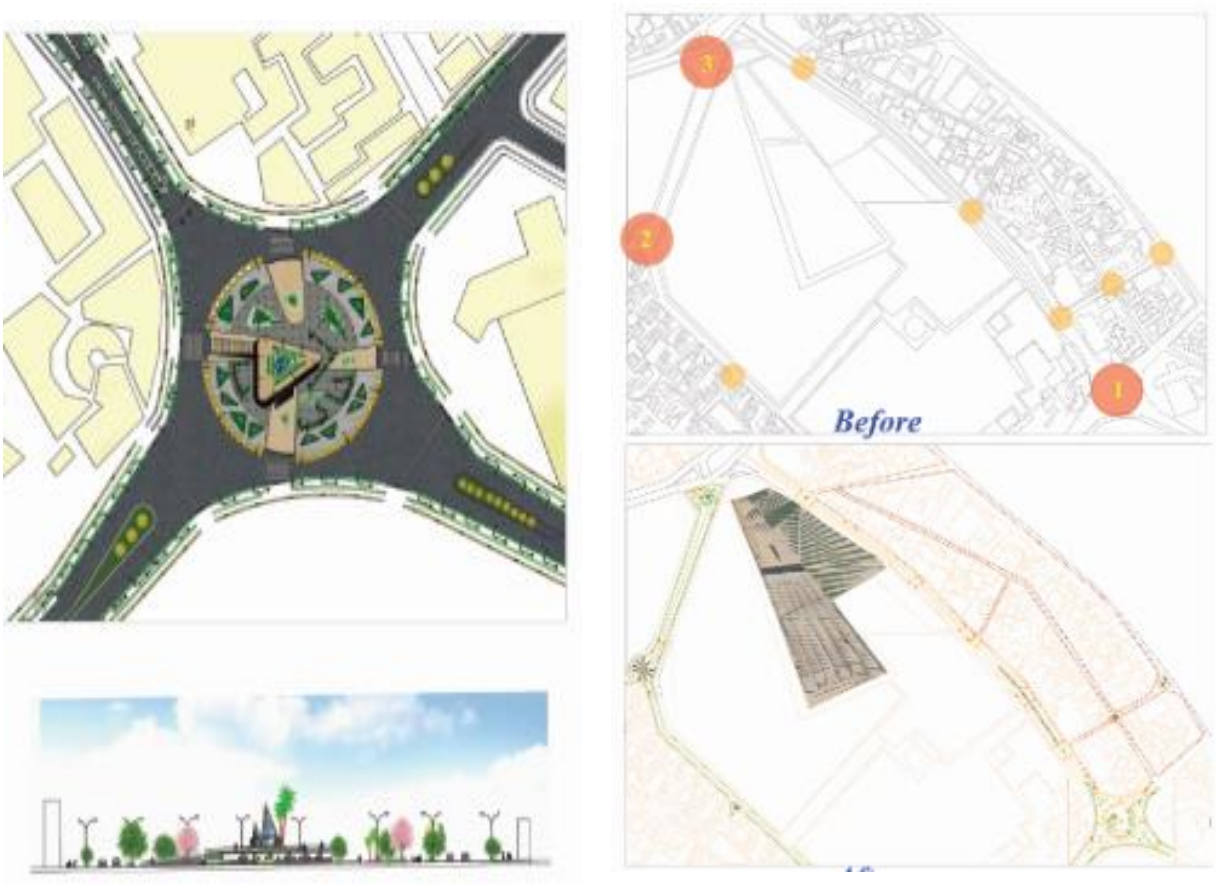

Fig 11: Shows GEM museum main nodes affecting its accessibility, the researcher

objective development. Assess the sustainable urban development indicators as a maximum impact factor. Upgrading the efficiency of streetscape function, as a basic role in urban development. Integrate the nation landmark with the urban context by creating creative recreational activities in its landmark nodes". Francois (2010) 
10-1-Design the streetscape responded to the desert-scape: The view of the (desert scape) pyramids plateau is shown as a vista view from the GEM museum parks only, as it is needed to be an axial view of the pyramids. The researcher goal is to decrease the building heights in the Desert-Scape, coping with the nature of sand dunes of its site typology to cope with site contours in a successive integrated way, to reach to a holistic perpetuation to the pyramid plateau by Defining The building form as a reflection to the site topography: Mainly it depends upon how to upgrade the urban context as a strategic location to apply aesthetical view, playing with light and shade in expanding the axial vision to the pyramids plateau, as a nation landmark, shown on its land use conditions, and its existed Construction to strengthen its impact.

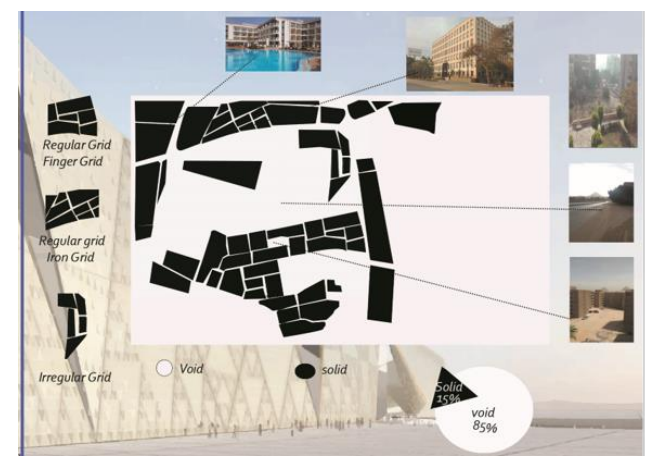

Fig 13 shows designed node of GEM urban context for nation landmark, by the researcher

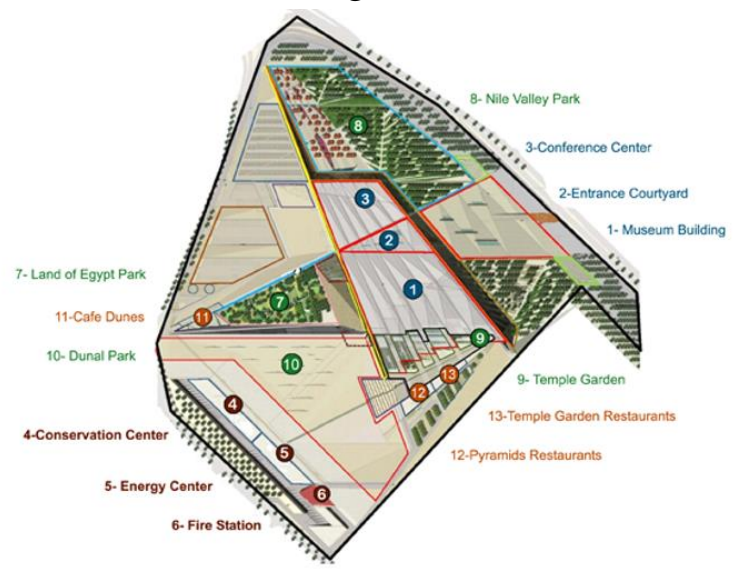

Fig 12 shows designed node of GEM urban context for nation landmark, by the

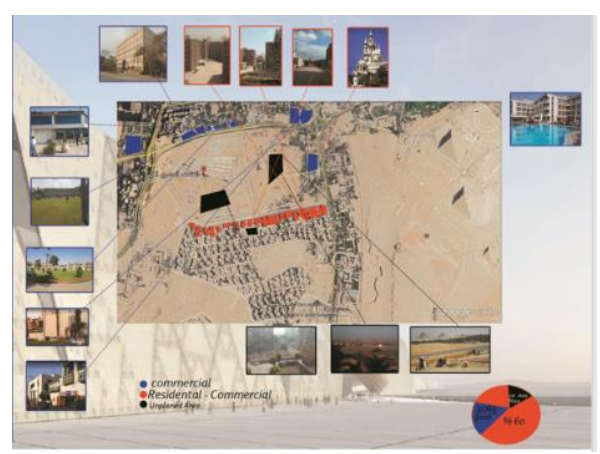

Fig 14 shows designed node of GEM urban context for nation landmark, by the researcher

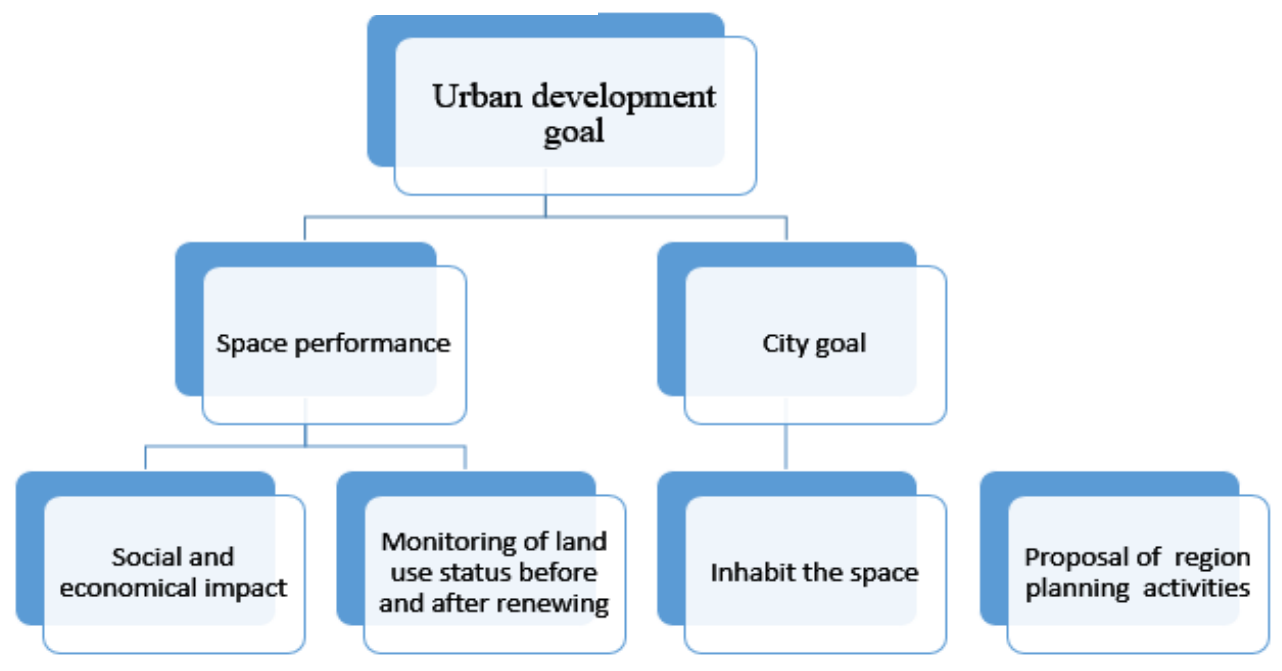

Fig 15: Shows urban development goal in regenerating city identity, by the researcher 


\section{0-2-The Ecological of urban development Consideration:}

Preserve the monumental site characteristics, avoiding the negative impact of surrounded buildings to the urban context, coping with the existed climatic conditions. So planning should be on The underground level, to provide good climatic conditions, such as differences in light, humidity, and heat to save the valuable treasures.

\section{0-3-Using raw materials in urban development of this monumental region:}

GEM museum plays a great role in identifying its region, as a real effective landmark, as

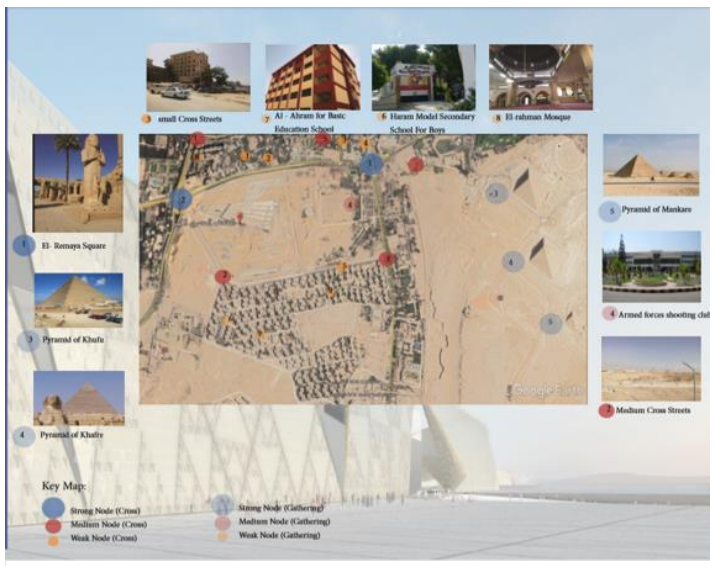

Fig 16 shows designed node of GEM urban context for nation landmark, by the researcher sustainable identity in using local raw building materials, by using bricks, alabaster and stones as a cladding material. So this is a basic fundamental in upgrading urban context, to apply intergradation in an effective way, shown in choosing the same colours of the site yellow sand, and beige in its building walls, as a bearing structures to sustain the region visual spirit, to achieve harmony between buildings, landmarks and its urban context.

\section{0-4- Upgrading the sensitive urban context of pyramids, with preserving its ecological value:}

So to upgrade the urban context, there are basic guidelines for designing the new urban development that should be applied, by assessing different alternative solutions, to choose the ideal decision achieving the virtual monumental identity. GEM museum plays a great important role in the awareness of the damage that may affect the pyramid plateau by the built environment shortage in sustainability, as there is no LEED surrounding it on the globe. So the urban development goal in this region is to turn the existing fact into green sustainable environment, by sustainable buildings. Egypt faces a great (Leadership in Energy and Environmental Design) council in Egypt.

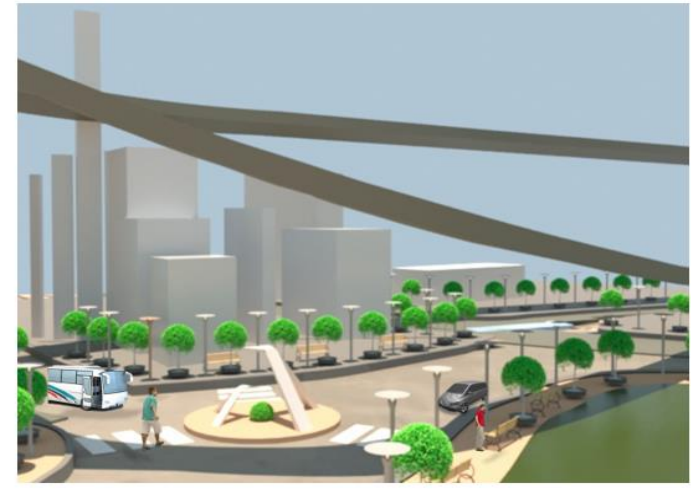

Fig 17 shows designed node of GEM urban context for nation landmark, by the researcher

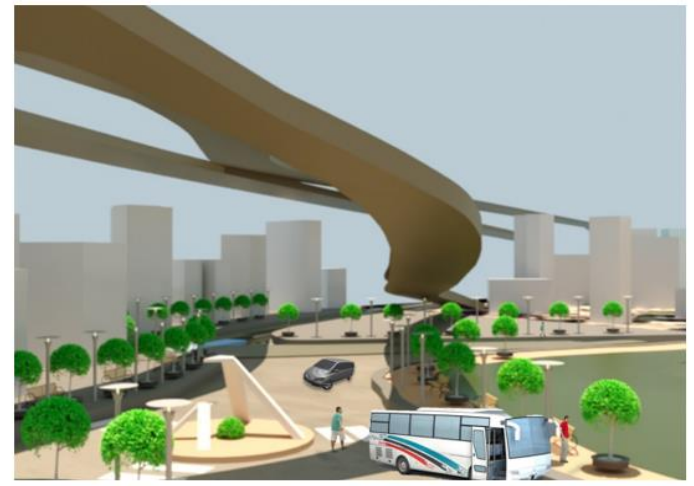

Fig 18 shows designed node of GEM urban context for nation landmark, by the researcher 


\section{0-4- Sustainability in urban context:}

The main goal of this paper is to save monumental environment, as a landmark for sustainability in urban context, by permitting natural day lighting to all buildings, to apply buffer zone upon sustainable rules.

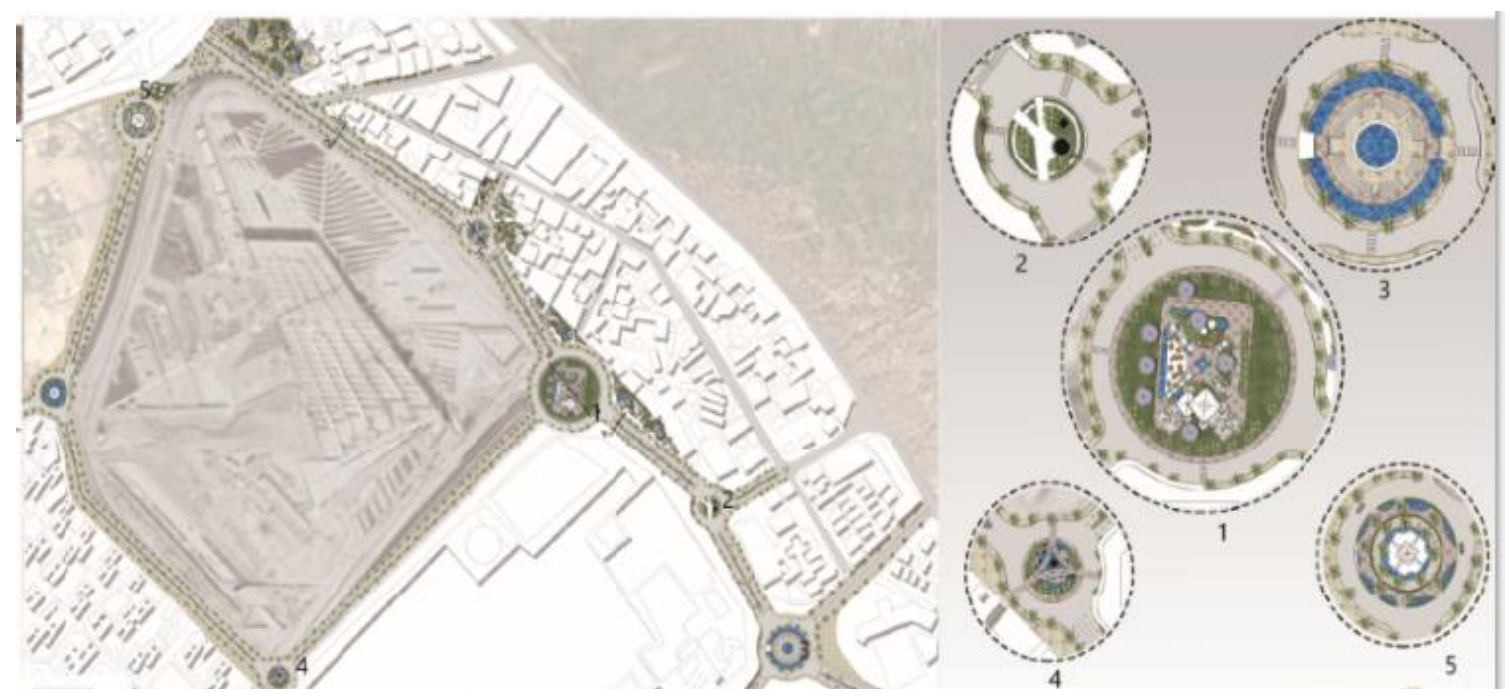

Fig 19 shows the designed approach for GEM urban context as a nation landmark, by the researcher

So to apply this nation landmark near pyramid plateau, there should be provided designed parking areas enough for the new land use implemented, to work in an efficient way, in the underground level, to apply green buildings. So the alternatives solutions should be assessed by its environmental impact, with integration the urban context as a main purpose for upgrading physical characteristics of the museum site, by guidelines of updated sustainable techniques in terms of environmental adaptability. In addition, develop strategies that improve social interaction to ensure a positive visitors' experience, that enhance socialization as cafes, restaurants.

\section{0-5- Study Bioclimatic comfort of outdoor spaces in the monumental urban context:}

So the urban development goal is to Control solar radiation in the outdoor, by increasing shaded areas, and implementing solar panels above it, as a way to generate electricity, in lightening our streets, that gives a whole shape for the streetscape, and it creates the holistic built environment, that reflects on the creation of shadow on external spaces, to acclimatize the spaces between the buildings. Design isolated hardscape for pavement, by increasing landscape areas among it, to avoid the overheating of the "buildings "envelope walls, with updated sustainable external paving.

\section{0-6-Investigating the primary urban development goal:}

By achieving the city government objectives in improving the accessibility by Improving public transport, and its efficiency in creating gathering areas, such as nodes near it. This region faces a great challenge in linking the immemorial past with the distant future. 


\section{1-Guiding methods for environmental solutions for outdoor development:}

Better adjustment to climate change in outdoor by:

Material: using light structure

Natural lighting: illuminates through transit areas

Typography: by building in the underground level instead, to avoid blocking the pyramids view, as well upgrading its environmental impact in providing constant temperatures, as soil plays a great role in isolation, in all seasons. (Carrion, F. (2005)p, l(3)).

Conservation Treatment: by saving the standardization, in documenting the urban features, upgrading urban development, urban sprawl.

Economic impact: Refunctioning vacant areas, in absorbing the increase in population, by increasing outdoor activities to upgrade the aesthetic view, and provides job opportunities too, by developing the local site resources.

Social impact: Create urban identity relevant to the monumental pyramid plateau, with upgrading its Health

Service Conditions. Providing safe system by high security. Protection of existed

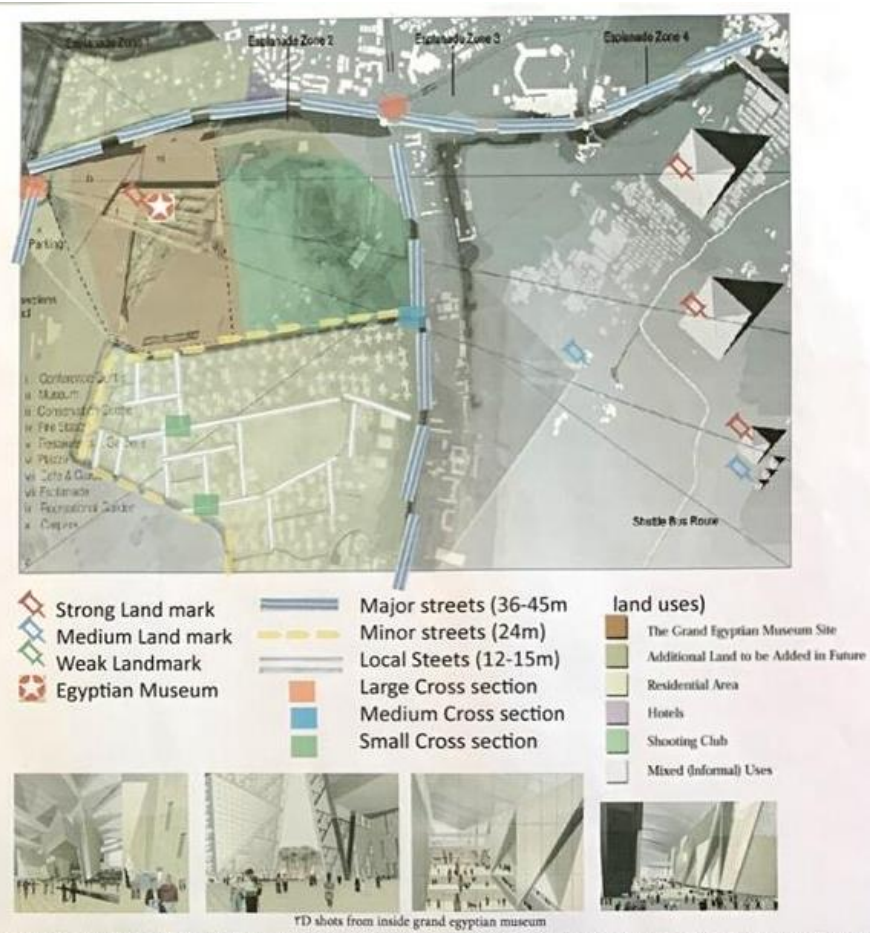

Fig 20 shows the designed approach nodes for GEM urban context as a nation landmark.

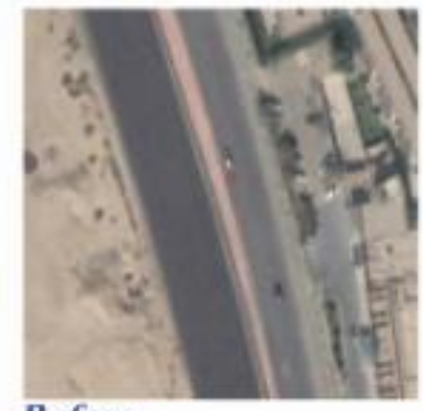

Before

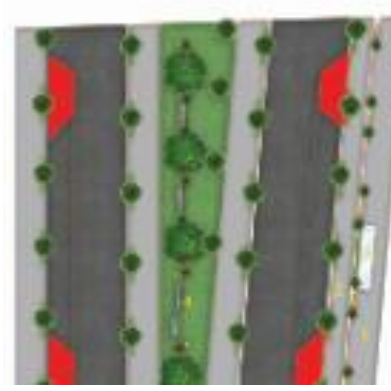

Fig 21 shows the designed approach streetscape for GEM as a nation landmark.

KeyMap: 1-floore Pattern I (pedestrian). 2-floore Pattern 2 (Bicycle lane). 3-Bus Stop.

4-Sitting Area.

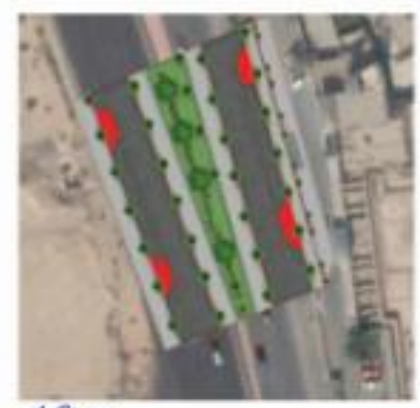

After 
agricultural lands from any erosion out of informal building. So GEM museum should be planned for entrainment landmark. Studying the human behaviour in this region, as it affects in a positive or negative impact after redesigning. The impact of human presence will alter the nature of this region environmentally.

Implement sustainable development: to analyse and study the impact of museum effect on the urban context environment for future generations. The sustainable urban development plan is to overcome constrains as an opportunity for upgrading measures, and to be controllable by country rules to preserve its value, by urban transformation.

The importance of GEM museum on archaeological development zone:As its location belongs to a larger archaeological site which includes the Pyramids Plateau, Hassana Dome, Abu Rawash and Abu Sir, and the Sakkara archaeological site. Designing "green belt" as a sustainable urban buffer at the Western part of the Greater Cairo Region is essential to protect it from prevailing desert wind. This zone can be used for recreational activities as an

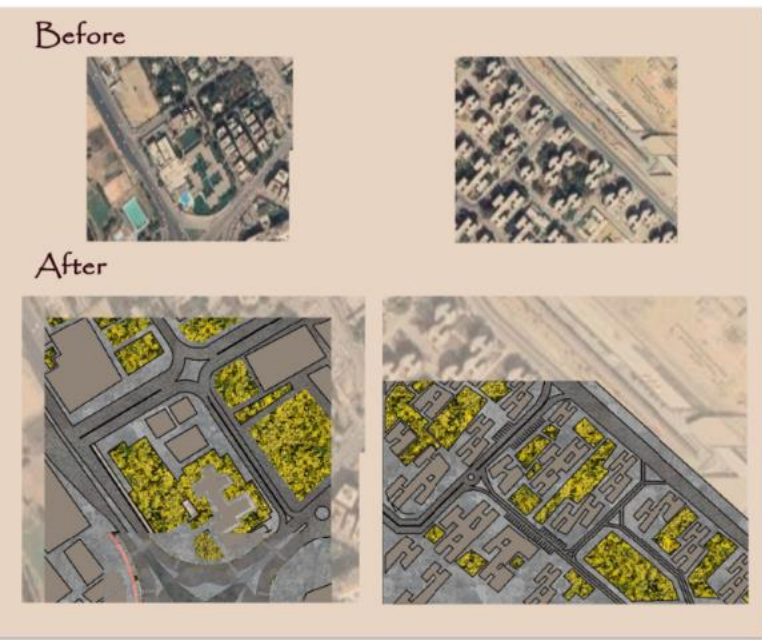

Fig 22 shows the suggested designed approach nodes for GEM urban context as a nation landmark, by the researcher.

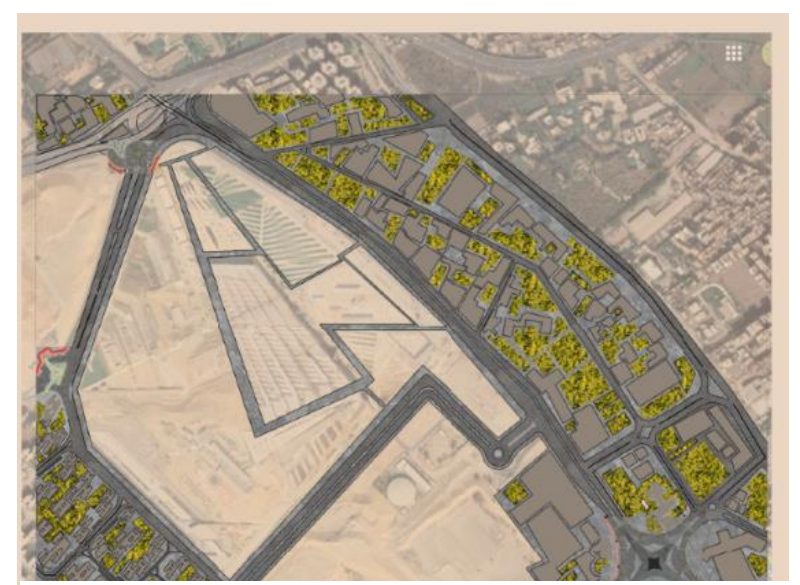

Fig 23 shows the designed planted plazas in the residential settlements nearby GEM museum, as a nation recreational activity, landmark, by the researcher. archaeological strip, based upon the Urban Development Plan goal of the Greater Cairo Region published in 1989. 


\section{2-Creating landmark with recreational activities:}

It is based upon urban planning, to implement efficient recreational activities, in the central nodes landmarks. In 1991 the Ministry of Culture shows its intension to build new museum, to reflect with recreational activities on the cultural facilities.

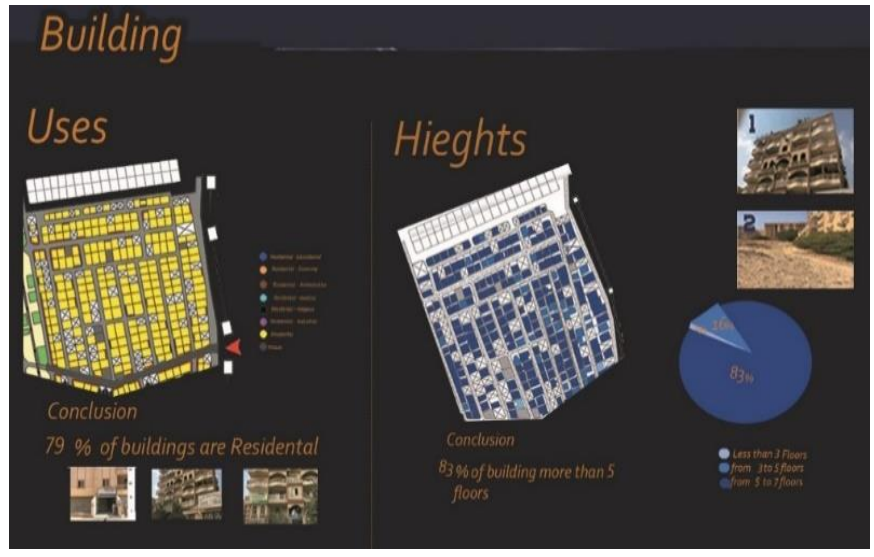

Fig 24 shows the designed approach nodes for GEM urban context as a nation landmark.

\section{2-1-Improving the accessibility of nation landmarks:}

By improving the public transport efficiency to facilitate accessibility of the nation landmark. Upgrade aesthetical view along streetscape, by creating green belt along the Ring Road, to protect the archaeological areas between the delta of the Nile and the Western desert, that is about 30 kilometres, along the North-South line from $\mathrm{Abu}$ Rawash archaeological site to that of Dahshur including $\mathrm{Abu}$ Sir Saqqara, and $\quad$ Abu Ghorab. The basics of urban development is to Classify the 1-Node 1 (REMAYASQUARE).
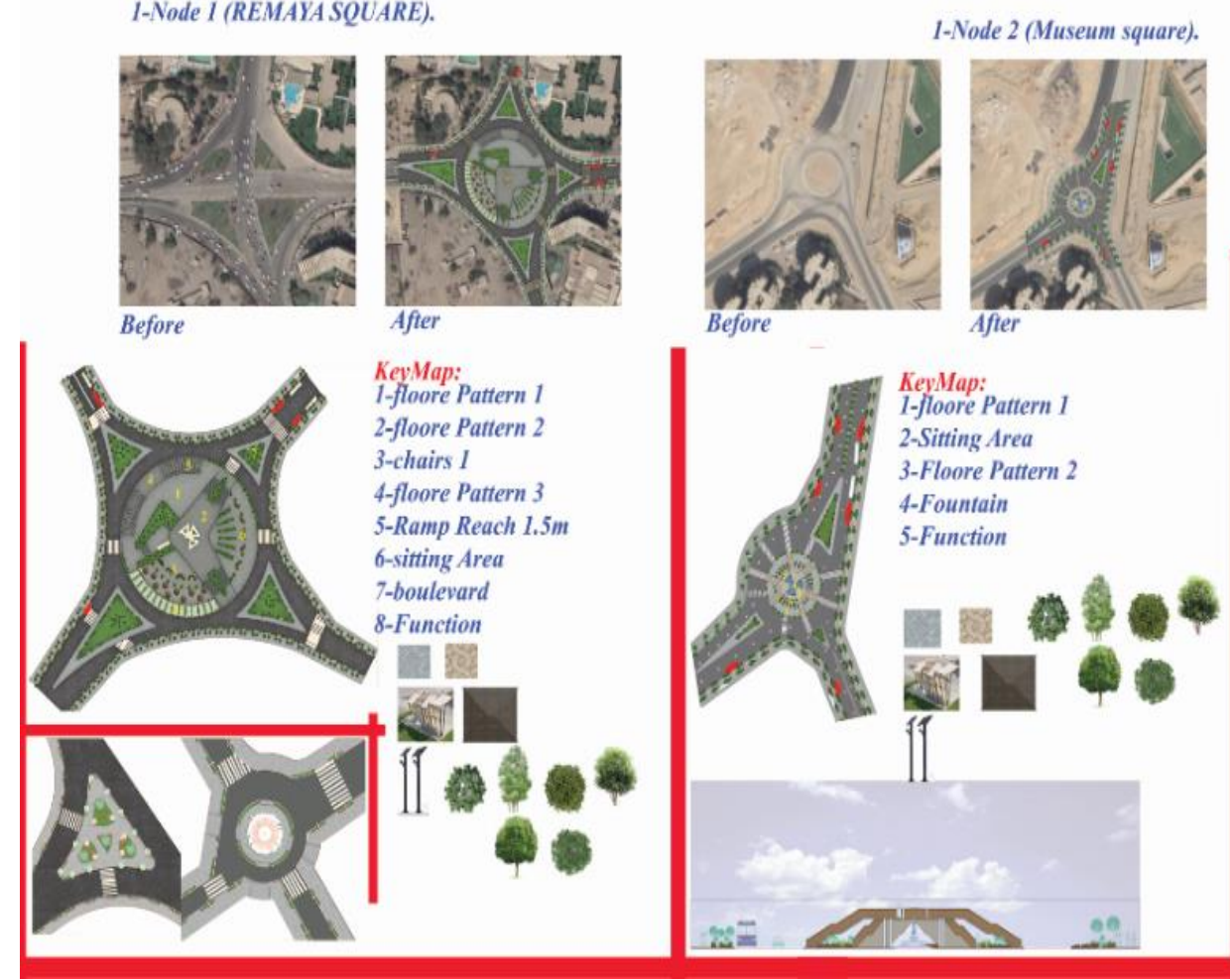

Fig 25: shows the designed approach nodes for GEM urban context as a nation landmark.

urban fabric upon its value, and its integration value, implement it upon restrictions on the housing settlements. Urban Development started in Cairo City is by invading the Giza agricultural land to the desert plateau border, since 1950. (

12-2-Greater Cairo urban expansion: So planning for nation landmarks has to be secured, by having border to identify its access, by using natural border green belt. To 
avoid the extension of informal housing settlements that cause a great threaten to this valuable region. So the main goal of urban development is to study environmental qualities for the exact circumstances, and for the future expansion impact on the region urban identity afterwards. The 1994 study gave some guide-lines for planning the archaeological site in Giza and its surroundings.

\section{2-3-Strengthen Urban upgrading as a tourism support in solving the region environmental problems:}

Enhancing the Urban Development Map for the museum site, between two typical landscapes in the Egyptian territory; the green lands and desert space. The museum creates new identity for urban quality as a solid core, as functionally it reflects on upgrading surrounded neighbours, as a surrounded area, by a positive effect, in converting it into tourist walkable flow to the pyramids plateau. Furthermore, the urban development changes The daily experience of human culture by changing the function, street image, building scale, and complexity recreational activities. (Law, R., \& Underwood, K., p.l(1), 131-147.

Designing urban development that can cope with climate change:

Upgrading bioclimatic performances, to improve its adjustment to daily and seasonal variations
Conservation of Egyptian raw materials, in using it in the deserts cape by updated sustainable techniques.

Fig 26 shows analytic methodology for strengthen GEM museum as a tourism support in the region

\section{2-4-Valid alternatives as an effective approach to upgrade the Giza Plateau:}

The museum is designed as hidden mass" the sunken city", where its geometry is inspired by the way the Egyptians used to preserve their mummies, as the approach circulation is planned to be linear route through the whole site, in an axial spine towards the Pyramids, aligned between different types of exhibit spaces. The museum concept reflects on its surrounding area as self-structured boxes, the same as footprint of the great pyramid that allows the flow between the complex spaces. So Modularity is fundamental basic in design, to apply unity in the monumental region. using satellite communication technology in reflecting specific periods a chronological demonstration of ancient Egyptian periods on buildings facades to reflect aspect of history on the street image.

Creating virtual display of the museums' as a link to the new Egyptian museum as a remarkable landmark tenacity for the visitor. Implementing shared cultural experience that 
reaches around the world through experiences for both physical and virtual Museum Visitors Upgrade the outdoor services in the museum site for the visitors of the archaeological area, such as increasing the shade in the outdoor resting areas, parking areas, and cafes. These services would be more effective to be placed in the promenade of the museum approach, and a strong linkage between the archaeological area of Giza. Observe the Pyramids, from all side views, not creating a border in vision, such as the road to Fayoum cut.( Tweed, C., \& Sutherland, M. (2007),p.83(1), 62-69).

\section{2-5-The character of GEM urban avenue as a central area:}

The location of the GEM, is considered a real sustainable landmark in addressing and regulating the urban extension in Giza, and the archaeological site of the western desert "Memphis and its necropolis with the Pyramids Field", as a World Heritage. The

\section{Upgrading urban GEM museum environmentally}
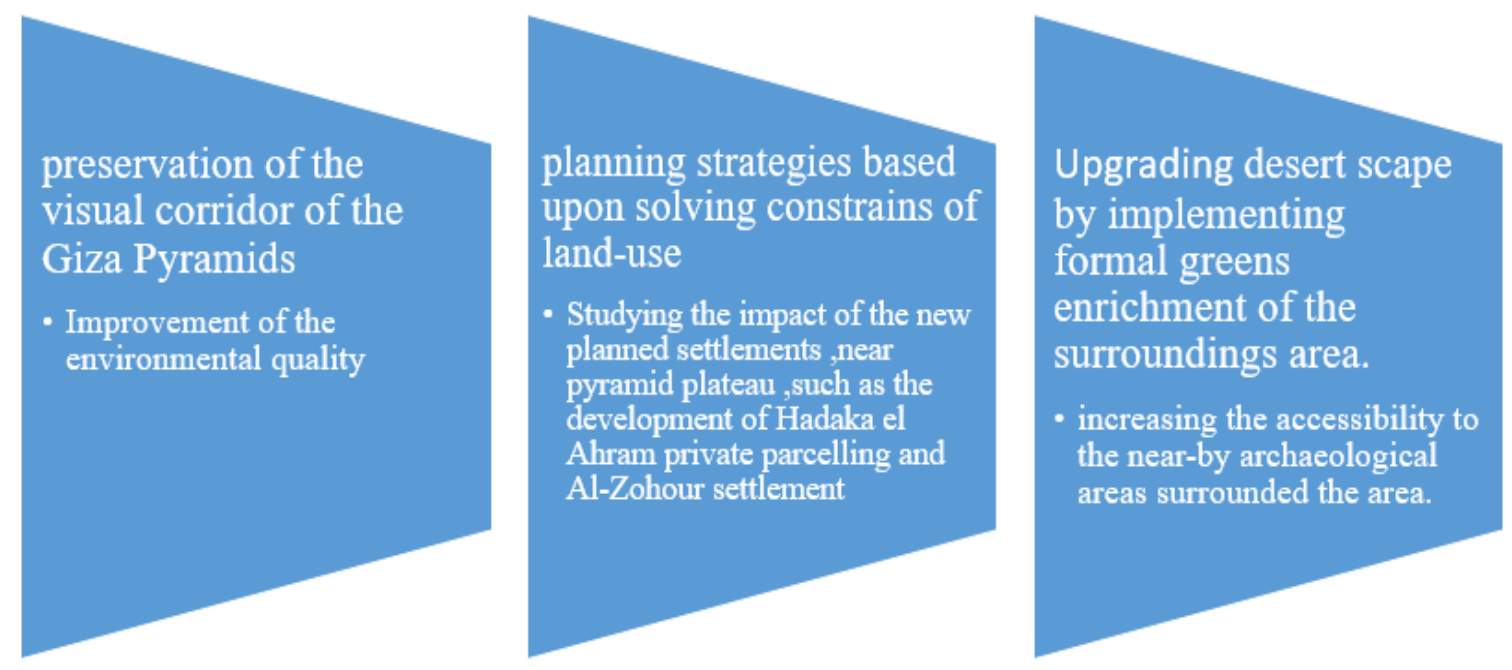

Fig 27 shows analytic methodology for strengthen GEM museum as a tourism support in the region

UNESCO show the great role of GME in attracting the archaeological site at the centre of preservation as a positive effective impact on society, as it is focusing more on the environmentally and sustainable eco-sensitive solutions. The urban development of museum region as a landmark urban nation type to fulfil society needs of the community, by upgrading museum facilities. The GEM Complex is planned to include lots of different facilities and support services, to cope with different type of users. The planned vision is to include various Commercial Investment Centre overlooking the Pyramids. As an Expanding international tourism visitation. (https://abes-online.com/en/guides/urbanplanning-urban-development-and-identity/) 


\section{2-6- The aesthetic view in the outdoor environment:}

Design the streetscape by using natural raw material, by using translucent stone wall, coping with desert landscape ,relevant to the museum project that is about $800 \quad \mathrm{~m}$ long .(http://gem.gov.eg).

10-3-Refunctioning efficient land use by updated recreational activities. Converting the place into real friendly place for disabilities and special needs .(http://gem.gov.eg).The social dimensions is much bigger weight than any other dimension, as it is the strongest linkage between economic and

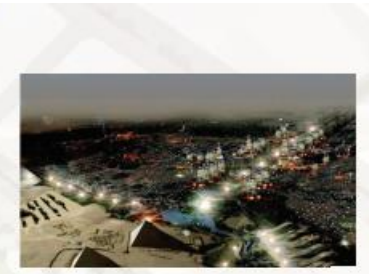

3D Shot After Redesign

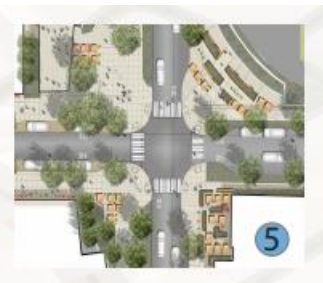

layout

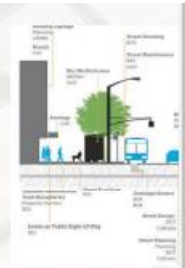

Road Sec

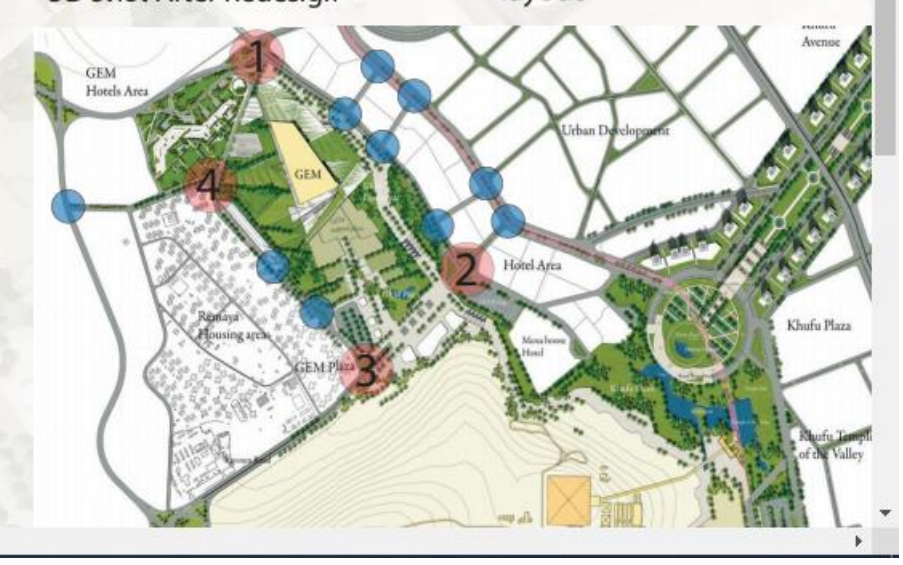

environmental issues.

Fig 28 shows proposed GEM museum urban development as a tourism support in the region

\section{3- Conclusion: scientific contribution:}

The paper purpose is to reduce the population in this monumental region, and upgrading its function, putting analytic methodology for assessing the impact of its external indicators, as analytic assessment to determine if the nation is proceeding the right direction on the path of urban. Sustainable development, refereeing to The Driving ForcePressure-State-Impact-Response(DFPSIR).

Due to the rapid urban changes in historic cities, it is important to monitor and conserve the urban identity facing this rapid change in life on a regular basis in order to balance with the different trend changes to compromise a city's distinctiveness. Designing sustainable historic centres as Urban identity mainly depends on the dual characters of "uniqueness", encompassing both dynamism and stability. Urban identity adds quality to the city needs that reflects by its impact on its surroundings. It is required to conserve city monumental landmarks to counter the standardization of spaces, which make them similar. This paper highlights on the future of cities to enhance policies for conserving its urban identity in a sustainable way. Urban regeneration of pyramid plateau has attempted to lay the ground and show the path through building a new urban identity inspired from the past. Such efforts need first to be assessed and evaluated, then decide whether to expand this experience to other historic cities. Urban planning policies have a great role in the transformation of an area to a divided condition, putting into consideration all scales of urban policies. Although many previous researchers discuss many national policies in Cairo, that are proven to be true in the selected case study, implementing these national local laws is great important, as it reflects effectivity on the region outcome. Therefore, the decision of a policy is assessed by its reflection in the specified area. Moreover, 
applying the policy depends mainly on the place, and its geographical urban context, as it plays a great role in any affected division. This means that we should avoid the generalized statement of policies affecting any division in Cairo. location and Scale are main factors that has to be taken in consideration for future research conducted on Cairo.

Moreover, each policy has as an individual entity. However, the time frame is an essential assessment tool in detecting policies with a long-term effect. This agrees with $\mathrm{K}$. Landman's systemic approach that shows the importance of urban policies role in division as a complex relation through a descriptive analysis. It is recommended to compare the relation with urban policies in different locations in Cairo, as a guide for selecting other locations. This can provide a fact answer, such as should we have unity in the influential urban policies in all locations, or whether should it be as prominent urban role. By considering more research in this field, issues such as diversity, difference, and social mix, on one hand, and segregation, fragmentation, and inequality, on the other hand, can then be accurately addressed. Creating a methodology for upgrading urban viability, and function performance in fulfilling nation urban development goal. (Bossel 2001). Analysing the external indicators affecting region, as variables that affects social interaction. Apply the City resilience in our urban planning to revive the city's ability to manage unexpected and expected risk related events. In addition, city's capacity to adapt to future challenges from a strategic and spatial perspective, to overcome urban governance obstacles out of rapid urbanisation, and effects of climate change. Use various assessing methods in measuring sustainable urban progress. For example, UK used the 'Trend' concept; to filtrate the sustainable indicators. Upgrade sustainable accessibility as a landmark image, as it has a great impact on the outdoor facilities in the surrounding area, mainly including sustainable, and shaded walkable network. Creating aesthetical features in the central nodes for traffic flow, with providing sufficient enough parking spaces, relevant to the new activities in the landmark, nodes. Creating sustainable streets as landmark for our heritage, by solving its energy consumption from water, drainage, to meet the society demands, through managing waste management in maintain it clean, and avoid air pollution. Moreover, Egypt's Fifth National Five-Year Plan for 2002-2007 is committed to engage community participation in being a decision-maker, including 'Decentralization and Development' and 'Participation in local development' (Ministry of Planning 2002).

Table 2: shows proposed GEM museum urban development as a tourism support in the region

\begin{tabular}{|l|l|l|l|}
\hline $\begin{array}{l}\text { Urban development } \\
\text { indicator }\end{array}$ & $\begin{array}{l}\text { Organizing } \\
\text { framework }\end{array}$ & $\begin{array}{l}\text { Sustainable } \\
\text { development } \\
\text { guidelines }\end{array}$ & $\begin{array}{l}\text { Response } \\
\text { approach }\end{array}$ \\
\hline $\begin{array}{l}\text { Study the centre of } \\
\text { urban }\end{array}$ & $\begin{array}{l}\text { Identifying } \\
\text { sustainable } \\
\text { development } \\
\text { indicators }\end{array}$ & $\begin{array}{l}\text { Coping with } \\
\text { climate change } \\
\text { and energy }\end{array}$ & $\begin{array}{l}\text { Focus on themes } \\
\text { and sub themes of } \\
\text { sustainable } \\
\text { development. }\end{array}$ \\
\hline $\begin{array}{l}\text { Analyse the crossroad } \\
\text { function }\end{array}$ & $\begin{array}{l}\text { Applying basic } \\
\text { guidelines for }\end{array}$ & $\begin{array}{l}\text { Surveying upon } \\
\text { analysing the }\end{array}$ & $\begin{array}{l}\text { Social, } \\
\text { environmental }\end{array}$ \\
\hline
\end{tabular}




\begin{tabular}{|c|c|c|c|}
\hline & $\begin{array}{l}\text { governmental urban } \\
\text { development }\end{array}$ & $\begin{array}{l}\text { consumption in } \\
\text { outdoor urban }\end{array}$ & $\begin{array}{l}\text { and economic } \\
\text { framework }\end{array}$ \\
\hline $\begin{array}{l}\text { Refunctioning nodes } \\
\text { by new recreational } \\
\text { activities }\end{array}$ & $\begin{array}{l}\text { Analysing the user } \\
\text { habit as a lifestyle } \\
\text { of the users, and } \\
\text { their resistance. }\end{array}$ & $\begin{array}{l}\text { Enhancing the } \\
\text { environment by } \\
\text { Protecting } \\
\text { natural } \\
\text { resources }\end{array}$ & $\begin{array}{l}\text { Integrating } \\
\text { transport and } \\
\text { urban } \\
\text { development }\end{array}$ \\
\hline $\begin{array}{l}\text { Studying vertical and } \\
\text { horizontal expansion }\end{array}$ & $\begin{array}{l}\text { Aspects that cope } \\
\text { with change in the } \\
\text { urban context }\end{array}$ & \begin{tabular}{ll}
\multicolumn{2}{l}{ Management of } \\
place in its \\
sustainable \\
function \\
preserve ,to \\
quality & its \\
&
\end{tabular} & $\begin{array}{l}\text { Create low carbon } \\
\text { cites. } \\
\text { Measuring the } \\
\text { density of each } \\
\text { zone on different } \\
\text { period of time. }\end{array}$ \\
\hline $\begin{array}{l}\text { Cultivate the national } \\
\text { unity through } \\
\text { aesthetic landmarks }\end{array}$ & $\begin{array}{l}\text { Increase physical } \\
\text { activity in urban to } \\
\text { avoid diseases, such } \\
\text { as increasing } \\
\text { walkability through } \\
\text { nodes. }\end{array}$ & $\begin{array}{l}\text { Create healthy } \\
\text { communities }\end{array}$ & $\begin{array}{l}\text { Creating activities } \\
\text { closer to each } \\
\text { other ,in good } \\
\text { network, } \\
\text { encouraging } \\
\text { walkability. }\end{array}$ \\
\hline $\begin{array}{l}\text { Assessing street } \\
\text { function, nodes after } \\
\text { usage }\end{array}$ & $\begin{array}{l}\text { Creating medium } \\
\text { trips by cycling }\end{array}$ & $\begin{array}{l}\text { Reduce energy } \\
\text { consumption in } \\
\text { outdoor urban } \\
\text { environment }\end{array}$ & $\begin{array}{l}\text { Creating compact } \\
\text { city ,needs time } \\
\text { and energy ,to } \\
\text { absorb urban } \\
\text { growth. }\end{array}$ \\
\hline $\begin{array}{l}\text { Complexity } \\
\text { functions , and its } \\
\text { impact }\end{array}$ & $\begin{array}{lr}\begin{array}{l}\text { Diversity } \\
\text { building }\end{array} & \text { in } \\
\text { fypes, } & \text { flexible } \\
\text { change in space. }\end{array}$ & $\begin{array}{l}\text { Reduce } \\
\text { consuming } \\
\text { material } \\
\text { resources } \\
\end{array}$ & $\begin{array}{l}\text { Create better mix } \\
\text { of activities and } \\
\text { services. }\end{array}$ \\
\hline $\begin{array}{lr}\text { Creating } & \text { new } \\
\text { perception } & \text { for } \\
\text { pyramid } & \text { plateau } \\
\text { vision } & \end{array}$ & $\begin{array}{l}\text { Applying comfort } \\
\text { in streetscape ,street } \\
\text { furniture, enhance } \\
\text { architectural } \\
\text { buildings details. }\end{array}$ & $\begin{array}{l}\text { Provide safety } \\
\text { to improve } \\
\text { accessibility } \\
\text { and mobility to } \\
\text { all nodes. }\end{array}$ & $\begin{array}{l}\text { Equitable city is } \\
\text { easily accessible } \\
\text { by all }\end{array}$ \\
\hline $\begin{array}{l}\text { Creating street } \\
\text { network harmony }\end{array}$ & $\begin{array}{l}\text { Depending } \\
\text { participation and } \\
\text { equity. Describes } \\
\text { the links between } \\
\text { human activities, } \\
\text { environmental } \\
\text { conditions and } \\
\text { policy } \\
\text { interventions. }\end{array}$ & $\begin{array}{l}\text { Promote } \\
\text { landscaping, } \\
\text { provide } \\
\text { facilities and } \\
\text { streetscape } \\
\text { amenities. } \\
\text { Having unity in } \\
\text { the urban } \\
\text { streetscape to } \\
\text { create nation } \\
\text { identity. }\end{array}$ & $\begin{array}{l}\text { Assessing service } \\
\text { size and its } \\
\text { capacity before } \\
\text { and after renewing }\end{array}$ \\
\hline alkability & $\begin{array}{l}\text { decentralization in } \\
\text { activities } \\
\text {,increasing society } \\
\text { participation }\end{array}$ & $\begin{array}{l}\text { examining the } \\
\text { comfort in the } \\
\text { outdoor. }\end{array}$ & $\begin{array}{l}\text { completing } \\
\text { Legislative } \\
\text { reform: }\end{array}$ \\
\hline
\end{tabular}




\begin{tabular}{|c|c|c|c|}
\hline $\begin{array}{l}\text { Optimum use of } \\
\text { resources, } \\
\text { transparency and } \\
\text { disclosure of data }\end{array}$ & $\begin{array}{l}\text { Legislative reform, } \\
\text { as a framework } \\
\text { around rural and } \\
\text { city, such as land- } \\
\text { use, sustainability } \\
\text { issues (and } \\
\text { Assessment } \\
\text { techniques upon the } \\
\text { its value to indicate } \\
\text { its effective } \\
\text { performance. }\end{array}$ & $\begin{array}{l}\text { Creating } \\
\text { recreational } \\
\text { activities by raw } \\
\text { material in } \\
\text { nodes }\end{array}$ & $\begin{array}{l}\text { opening up to } \\
\text { Constitutional } \\
\text { changes: } \\
\text { transparent } \\
\text { contact between } \\
\text { political parties } \\
\text { and the people }\end{array}$ \\
\hline $\begin{array}{l}\text { Conservation } \\
\text { Treatment, } \\
\text { Standardization by } \\
\text { practical treatment }\end{array}$ & $\begin{array}{l}\text { Assessment based } \\
\text { on the value of } \\
\text { individual } \\
\text { indicators. }\end{array}$ & $\begin{array}{l}\text { The vary in } \\
\text { facilities target } \\
\text { concepts. }\end{array}$ & $\begin{array}{l}\text { apply regular } \\
\text { monitoring on the } \\
\text { state of the } \\
\text { environmental } \\
\text { development } \\
\text { process. }\end{array}$ \\
\hline $\begin{array}{l}\text { 'Target assessment } \\
\text { method for indicators. } \\
\text { UN-CSD used the ' } \\
\text { concept with the } \\
\text { established goals }\end{array}$ & $\begin{array}{l}\text { increasing } \\
\text { understanding and } \\
\text { Raising awareness } \\
\text { of sustainable } \\
\text { development }\end{array}$ & $\begin{array}{l}\text { comprehensive } \\
\text { overview of the } \\
\text { recreational } \\
\text { activities in } \\
\text { nodes. }\end{array}$ & $\begin{array}{l}\text { monitor progress } \\
\text { towards region } \\
\text { sustainable } \\
\text { development. }\end{array}$ \\
\hline
\end{tabular}

\section{References:}

1. Adham, K. (2008). Rediscovering the island: Doha's urbanity from pearls to spectacle. The evolving Arab city: Tradition, modernity and urban development, 218-257

2. Al-Kholaifi, M. J. (2006). The traditional architecture in Qatar. Doha: National Council for Culture, Arts and Heritage, Museum and Antiquities Department.

3. Attia, S., Shafik, Z., \& Ibrahim, A. (Eds.). (2018). New Cities and Community Extensions in Egypt and the Middle East: Visions and Challenges. Springer.

4. Boussaa, D. (2003). Dubai: The search for identity. People, places and sustainability, 51-60.

5. Boussaa, D. (2014). Al Asmakh historic district in Doha, Qatar: from an urban slum to living heritage. Journal of Architectural Conservation, 20(1), 2-15.

6. Boussaa, D. (2016). Cities in the Gulf: Rapid urban development and the search for identity in a global world. In Population growth and rapid urbanization in the developing world (pp. 166-191). IGI Global.

7. Boussaa, D. (2018). Urban regeneration and the search for identity in historic cities. Sustainability, 10(1), 48.

8. Carrion, F. (2005). The historical centre as an object of desire. City \& time, 1(3).

9. Caton, S., \& Ardalan, N. (2010). New Arab Urbanism, the Challenge to Sustainability and Culture in the Gulf. Harvard Kennedy School: Cambridge, MA, USA. 
10. Chen, Y. (2019). ANALYZING DETERMINANTS OF URBAN VIBRANCY-A BIG DATA APPROACH ON CONNECTING BUILT ENVIRONMENT, SOCIAL ACTIVITY, AND IMAGES OF PLACES.

11. Cheshmehzangi, A. (2012). Identity and public realm. Procedia-Social and Behavioral Sciences, 50, 307-317.

12. Cuthbert, A. R. (2007). Urban design: requiem for an era-review and critique of the last 50 years. Urban Design International, 12(4), 177-223.

13. Duncan Jr, J. S. (1973). Landscape taste as a symbol of group identity: A Westchester County village. Geographical Review, 334-355.

14. De Wet, M. M. M. (2017). The variables influencing developmental local governance to promote sustainable communities and cities in South Africa (Doctoral dissertation, University of Johannesburg).

15. Derek, A. (2009). Three Stories of Salford: Transformation, Identity and Metropolitan Peripheries. North West Geography, 9, 10-15.

16. Evans, G. (2005). Measure for measure: Evaluating the evidence of culture's contribution to regeneration. Urban studies, 42(5-6), 959-983.

17. Fanuzzi, A. R., Castronovo, A. R., Cherniavsky, B. E., Brady, B. M. P., di Leonardo, C. M., Shields, C. D. S., ... \& Edwards, D. B. H. Skip to content.

18. Gharib, R. (2014). Requalifying the Historic Centre of Doha: From Locality to Globalization. Conservation and Management of Archaeological Sites, 16(2), 105116.

19. Hague, C., \& Jenkins, P. (Eds.). (2005). Place identity, participation and planning (Vol. 7). Psychology Press.

20. Hospers, G. J. (2010). Lynch's The image of the city after 50 years: City marketing lessons from an urban planning classic.

21. Law, R., \& Underwood, K. (2012). Msheireb heart of Doha: an alternative approach to urbanism in the gulf region. International Journal of Islamic Architecture, 1(1), 131-147.

22. Lucci, P., Bhatkal, T., Khan, A., \& Berliner, T. (2015). What works in improving the living conditions of slum dwellers. A Review of the Evidence Across Four Programmes.

23. NEW, B. BUILDING NEW URBAN IDENTITIES.

24. Patrão, C., Moura, P., \& Almeida, A. T. D. (2020). Review of Smart City Assessment Tools. Smart Cities, 3(4), 1117-1132.

25. Rashed, M. G. (2015). Cairo and its Museums_From Multiculturalism to Leadership in Sustainable Development. Cities, Museums and Soft Power, 165-172.

26. Salama, A. M., \& Wiedman, F. (2013). Demystifying Doha: On Architecture and Urbanism in an Emerging City, 43-45. Farnham, England: Ashgate.

27. Tweed, C., \& Sutherland, M. (2007). Built cultural heritage and sustainable urban development. Landscape and urban planning, 83(1), 62-69.

28. http://archnet.org/system/publications/contents/8722/original/DTP101221.pdf?139 6271815 (accessed on 10 June 2016).

29. https://abes-online.com/en/guides/urban-planning-urban-development-andidentity/ 